\title{
Öğrencilerin Bilimsel Süreç Becerilerine Eleştirel Pedagojik İlkeler Bağlamında Yaklaşım
}

\section{Approach to Scientific Process Skills of Students in the Context of Critical Pedagogical Principles}

\author{
Ayhan Aksakalli a,* \\ ${ }^{a}$ Dr, Fen Bilimleri Öğretmeni, Milli Eğitim Bakanlığı, Erzurum/Türkiye. \\ ORCID: 0000-0001-6281-5828
}

\section{MAKALE BİLGİṠ \\ Makale Geçmişi: \\ Başvuru tarihi: 02 Eylül 2019 \\ Düzeltme tarihi: 27 Şubat 2020 \\ Kabul tarihi: 12 Mart 2020}

\section{Anahtar Kelimeler:}

Eleştirel pedagoji

Fen eğitimi

Bilimsel süreç becerileri.
ÖZ

Bu çalışma, öğrencilerdeki bilimsel süreç becerilerine eleştirel pedagoji ilkeleri dikkate alınıp yaklaşıldığında meydana gelebilecek değişimleri belirlemek amacıyla yapılmıştır. Araştırmada nicel yöntemlerden eşdeğer olmayan karşılaştırma grubu deseni kullanılmıştır. Araştırmanın çalışma grubunu bir devlet okulunun iki şubesinde eleştirel pedagoji ilkelerine göre üç şubesinde ise mevcut fen bilimleri öğretim programına göre fen öğretimi yapılan beş farklı şubeden 129 sekizinci sınıf öğrencileri oluşturmaktadır. Uygulamalar 24 hafta boyunca haftada dört saat olmak üzere sekizinci sınıf fen bilimleri dersinde yürütülmüştür. Veri toplamak için öğrenciler tarafından hazırlanan fen bilimleri öğretim programı ve bilimsel süreç beceri testi kullanılmıştır. Veri analizi olarak betimsel istatistik, tek faktörlü varyans analizi ve ilişkili örneklem t-testi kullanılmıştır. Araştırma sonuçları, deney grubu öğrencilerinin kontrol grubu öğrencilerine göre bilimsel süreç becerilerinde istatistiksel olarak anlamlı farklılaşmalar olduğunu göstermiştir.

\section{A B S T R A C T}

The aim of this study is to determine the changes that may arise when students' scientific process skills are approached with critical pedagogical principles. The research was quantitative in appearance and non-equivalent comparison group design was used. The study group consisted of 129 eighth grade students from five different classes in a public school. In two of the classes, science teaching was conducted according to the principles of critical pedagogy and in the other three classes according to the existing science curriculum. The applications were carried out in the eighth grade science course, four hours a week for 24 weeks. Science curriculum and scientific process skill test prepared by students were used to collect data. The reliability coefficient of the test was between $0.60 \leq \alpha \leq 0.80$ in the sample area. Descriptive statistics, one-factor analysis of variance and related t-test were considered as data analysis. The results of the study showed that the scientific process skills of the experimental group students were statistically significant differences compared to the control group students.

\section{Giris}

İçinde bulunduğumuz hayatı açıklama çabaları olarak tanımlayabileceğimiz bilim, yüzyıllar önce ortaya çıkmış, öne sürülen düşüncelerin zaman içerisinde gelişmesiyle birlikte bugünkü halini almıştır.

$\mathrm{Bu}$ doğrultuda yaşamı anlamak ve yorumlamak için gözlemler yoluyla elde edilen verileri çürütmek adına ortaya konulan temel zihinsel süreçler bilim olarak karşımıza çıkmaktadır (Özoğlu, 1994). Başka bir deyiş ile bilim, gerçekleri bulma ve bu gerçeklerle ilgili bilgileri düzenleyerek ortaya çıkardığ 1 teorileri gerçekleştirmek adına yaptığı uğraşların toplamı diyebiliriz (Arslan ve Tertemiz, 2004). Bu anlamda bilim bir problemi çözmek için gerekli araştırmaların tümünü kullanır diyebiliriz (Ramig, Bailer, \& Ramsey, 1995).

Bilimin oluşmasında doğal olarak bilim insanlarının yaptığı keşiflerin büyük rolü vardır (Abruscato, 2000). Özellikle bu insanlar gözlenen olayları açıklayarak olaylar arasındaki bağlantılar hakkında bir sonuca varmak için genellemeler yapmıştır (Arslan ve Tertemiz, 2004). Bilim insanları bu genellemeleri yaparken bilimsel süreç becerilerini

\footnotetext{
* Sorumlu Yazar/Corresponding author.

e-posta: tolga250606@hotmail.com
} 
kullanırlar. Başka bir ifade ile gerek açıklamaları gerekse genellemeleri "bilimsel süreç" denen akılcı düzenlemeler ile elde ederler. Bilim insanları genellemeler yaparken ön yargılardan uzak kalmakla birlikte nicel gözlemleri daha çok dikkate alırlar (Arslan ve Tertemiz, 2004).

Kişiler, herhangi bir problemin çözüm süresinde doğru kararlar alabilmek adına birtakım parametrelere başvururlar. $\mathrm{Bu}$ parametreler içerisinde özellikle gelenekler, otorite ve kişisel deneyimler gelmektedir. Bu parametrelerin her biri doğal olarak problemin çözümünde çokta etkili olduğu söylenemez. Yıldırım'ın (1985) da dediği gibi problem çözümünde dikkate alınacak şey "bilim" ve onun "bilimsel yöntemleridir". Bu anlamda bilim: evrendeki olayların bir bölümünü ele alıp çeşitli yöntem ve deneylerle yasalara ulaşmak için takip ettiği düzenli ve tutarlı bilgi yolu olarak da tanımlanabilir.

Bilimsel yöntem, bir akıl yürütme sürecidir. Özellikle problem çözümü ve bunlarla ilgili çalışmaların yürütülmesinde mantıksal bakış açısı gerektirir ve bir süreci kapsar. $\mathrm{Bu}$ süreç ise farklı işlem seviyelerinde meydana gelir. Bilimsel yöntem kullanarak bilgiyi elde etme ve üretme becerileri, bilimsel süreç becerileri olarak tanımlanabilir (Arslan ve Tertemiz, 2004). Başka bir deyişle bilgiyi elde etmede, problemler üzerinde kafa yormada ve elde edilen sonuçları formüle etmek için kullanılan düşünme becerileri bilimsel süreç becerileri olarak da karşımıza çıkmaktadır (Lind, 1998; akt. Temiz ve Tan, 2003).

Hurd (1991), günümüzdeki toplumlarda eğitimin geleneksel tarzda yürütüldüğünden dolayı eğitimin doktrine etme işlevi görüp bilimsel düşünmenin ön plana çıkmadığını ileri sürerek öğrencilerin çoğunun her ne kadar okullardan mezun olsalar dahi bilimsel okuryazarlığa sahip olmadığını da belirtmektedir. Benzer şekilde Kılıç ve diğerleri (2001) bilim ve teknoloji okuryazarlığı için gerekli olan bilgilerin öğrenilmesi gerektiğini ifade ederek devam ettirilebilir bir kalkınma ve demokrasi için herkesin bu doğrultuda yetiştirilmesi gerektiğini ileri sürmektedir. Arslan ve Tertemiz (2004), eğitim sisteminde çoğunlukla egemen olan ezberci yap1, bilgiyi bilimsel yaklaşımlarda bulunması gereken bir olgu olarak görmeyip salt kendinden tutarlı bir olgu olarak verdiğinden dolayı insan zihnini, soruşturan ve sorgulayan değil, her şeyi olduğu gibi kabul eden pasif zihinlere dönüştürdüğünü ileri sürmektedir. Bu yaklaşım geleneksel eğitimin mirası olan ezberci eğitimin bir sonucu olmakla birlikte, bilimsel ve özgür düşünme yaklaşımlarına ters düşmektedir. $\mathrm{Bu}$ durumdan kurtulabilmek adına ise bilimin evrensel kimliği eğitim ile eş güdümlü olarak yol alması gerekmektedir.

Karasar (2004), insanoğlunun bilim üretme çabasının bu yaklaşıma olan güveninin somut bir görünüm olduğunu ifade ederek bilim üretiminde ve tüketiminde ileri olan ülkelerin bilimin evrensel ilkelerine bağlı kalmasının gelişmişlik düzeylerinde de bir fark yarattığını ileri sürmektedir. Özoğlu (1994), bilimsel bilgilerin elde edilmesinin bilimsel düşünmeden geçtiğini ifade ederek, bilimin ancak bu şekilde oluşabileceğini iddia etmektedir. Eğitim, bilimsel düşünmeyi okul öncesinden başlayıp, örgün eğitimin son aşamasına kadar sistemli bir şekilde bireylere aktarmak zorundadır (Arslan ve Tertemiz, 2004). Bu ise ancak öğretim programlarına bilimsel düşünme becerilerini kazanım olarak koyulması ile sağlanabilir (Özoğlu, 1994). Bu konuda Arslan'ın (1995) yaptığı bir çalışmada ilkokul öğrencilerinde hangi tür bilimsel süreç becerilerinin açığa çıktığı araştırılmıştır. Özellikle bilimsel süreç becerilerinden olan gözlem, açıklama, tahmin, soru sorma, araştırma, iletişim kurma, planlama, üretme becerilerinin öğrencilerde nasıl açığa çıktığı sorusu ile ilgilenilmiştir. Aynı paralelde Dökme (2005) ise yaptığı araştırmada 6.sınıf fen bilgisi ders kitabının sınıflama, tahmin, iletişim gibi temel bilimsel süreç becerileri açısından eksik olduğunu ifade etmiştir. Benzer şekilde Roberts ve Gott (1999), biyologlar tarafından yapılan bazı çalışmalar üzerinden yaptıkları araştırmada öğrencilere bilimsel süreçleri kazandırabilmek için gerekli imkanların verilmesi gerektiğini belirtmişlerdir.

Mevcut eğitim sistemi içerisinde yer alan öğretmenler gerek ders kitapları gerekse diğer materyaller açısından bilim insanlarının kullandığı yöntemleri sadece yorumlamakla yetinmektedirler. Bu anlamda sınıfta öğretim adına kullanılacak her şey bilimsel yöntem ve bilimsel süreç becerilerinin gerçek anlamları dikkate alınarak sunulması gerekmektedir. Çocukların yaşamları bilimsel araştırma sonuçlarından etkilendiğinden dolayı bilimsel süreçlerin nasıl meydana geldiğini anlamaya ihtiyaçları vardır (Arslan ve Tertemiz, 2004). Özellikle kısa adı PISA olan uluslararası öğrenci değerlendirme sonuçlarına baktığımızda bilimsel süreçlerin öğrenciler açısından ne kadar önemli olduğunu bir kez daha görmekteyiz. Bu program 2003 yılında 15 yaş grubu öğrencilerine okuduğunu anlama, fen ve matematik konularındaki yeterliliklerini belirlemek amacıyla yaptığ değerlendirmeler sonucunda Türkiye 41 ülke arasından fen alanında 36. matematikte ise 35. sırada olduğunu göstermiştir. Aynı şekilde 2015 yılında yapılan değerlendirmeler sonucunda ise 72 ülke arasında; fende 52. matematikte 49 . ve okuduğunu anlamada ise 50. sirada yer almıştır. 2003'ten 2015'e kadar olan PİSA sonuçları değerlendirildiğinde okullar arasındaki başarı farklılığında en göze çarpan ülke Türkiye olmuştur (Akt. Hazır, 2006). Bu sınavın bilimsel süreç becerilerini de ölçtüğünü dikkate aldığımızda sonuçların hiç de iyi olmadığını söyleyebiliriz. $\mathrm{Bu}$ sonuçlar üzerinde kafa yoran kesime göre bu durumun tek nedeni ezberci eğitim sistemi olduğu yönündedir (Akar, 2007).

Yurt içi çalışmalara baktığımızda benzer sonuçlarla karşılaşmaktayız. Örneğin Pekmez'in (2001) yaptığı bir araştırmada İzmir ilinde 24 fen bilgisi öğretmeniyle yaptığ görüşme sonucunda, bilimsel süreçlerle ilgili bilgilerin dikkate şayan bir şekilde yetersiz olduğunu belirtmiştir. Temiz'in (2001) yaptığı bir çalışmada ise öğrencilerin liseden önceki eğitim öğretim hayatında bilimsel süreç becerilerinin yeterli düzeyde olmadığını tespit etmiştir.

Geban (1990), yaptığı bir çalışmada ise kimya dersi ve bilimsel araştırma yöntemlerine dayalı laboratuvar çalışması ile kimya dersi ve kimya deneylerinin bilgisayar yoluyla gösterilmesi yöntemlerinin; öğrencilerin kimya başarılarına, bilimsel işlem becerilerine ve kimyaya karşı olan tutumlarında etkisini incelenmiştir. Ayrıca bu öğretim metotlarını, geleneksel yöntem ile karşılaştırmıştır. Yapılan analizler bilimsel araştırma yöntemlerine dayalı laboratuvar çalışması ile kimya deneylerinin bilgisayar yoluyla gösterilmesi yönteminin kimya başarısında ve bilimsel işlem becerisinde geleneksel yöntemden daha etkili olduğunu göstermiştir. Dökme (2005) ise şu an ülkemizde kullanılmakta olan 6. sınıf fen bilimleri ders kitabını bilimsel süreç becerileri yönünden analiz etmiştir. Araştırmacı, 
kitapta yer alan etkinliklerin belli yüzdeliklerle 12 temel süreç becerisini de kapsadığını belirtmiștir. Ancak sınıflama, tahmin, iletişim gibi temel süreç becerileri ile hipotez kurma becerisinin diğer becerilere göre daha az sayıda olduğunu ve süreç becerilerinin etkinlikler boyunca dağılımının sistematik olmadığı belirtmiştir. Benzer şekilde Temiz (2001), lise 1. sınıf fizik dersi programının, bilimsel süreç becerilerin gelişiminde ne derece etkili olduğunu araştırmıştır. Araştırma sonuçları, örneklemdeki öğrencilerin, liseden önceki eğitim öğretim sürecinde bilimsel süreç becerilerinin yeterince geliştirilemediği ve lise 1.sınıf fizik programının öğrencilerin bilimsel süreç becerilerini geliştirmede yeterli olmadığı sonucunu vermiştir.

Tüm bu sonuçlar geleneksel eğitim anlayışında öğretmenler öğrencilere konuları aktarır, öğrencilerde herhangi bir sorgulama yapmadan sadece kendilerine verilen bilgileri ezberler mantığına işaret etmektedir. Böyle bir eğitim anlayışında öğrencilerin ezberlemek dişında çok fazla da bir seçenekleri olmadıklarını söyleyebiliriz. Çünkü verilen bilgiler birbirinden kopuk ve bir o kadar da ilişkisizdir. Tek kaygısı sınavı geçmek olan öğrenciler açısından ezberlemek yapabilecekleri terk alternatif yol olarak durmaktadır (Akar, 2007).

$\mathrm{Bu}$ doğrultuda geleneksel eğitim programları insanlık için önemli olan bilgileri sadece ezberletmiştir. Fakat reel yaşam bunun pratikte pek de mümkün olmadığını göstermektedir. Bunun yerine bilgiyi ezberleyen değil, bilimsel okuryazarlığ daha çok ön plana çıkarmak gerekmektedir. $\mathrm{Bu}$ anlamda bilimsel süreç becerileri geleneksel öğretim metotlarından ziyade çağdaş ve farklı ilkelerle öğretilip eğitim programları içerisinde yerini almalıdır (Akar, 2007). Ayaz ve diğerleri (1994), ABD'nin 1950'li yıllara dek uyguladığı fen bilimleri programında "bilimsel bilgiler" kısmı daha çok ön plana çıkarılırken, bilgi edinme yollarının ihmal edildiğini söylemektedir. Özellikle 1957'de Rusların Sputnik uzay aracını fırlatması Amerika'da fen bilimleri eğitiminin ve bilgi edinme yollarının yeniden gözden geçirme gerekliliğini hızlandırdıklarını da ifade etmektedirler. Bu anlamda bilimsel süreç becerileri bilimi öğrenme ve anlamak için kullanılabileceği gibi fen eğitiminin de asıl amacıdır. Bilimsel süreç becerileri sadece bilim adamlarının bilmesi gereken bir şey değil aynı zamanda toplumun her kesimin de bilimsel okuryazarlık adına ihtiyaç duyması gereken bir gereksinim olarak kendini göstermektedir (Huppert, Lomask, \& Lazarorcitz, 2002). Çünkü bu beceriler, okulda, iş yerlerinde ve yaşamda son derece önemli beceriler olarak açığa çıkmaktadır (Rillero, 1998).

\section{Literatür}

\subsection{Bilimsel Süreç Becerileri}

Bilimsel süreç becerileri, öğrencilerin derslerde öğrenmelerini kolaylaştırarak daha aktif olmalarını sağlayıp öğrencilerin öğrendikleri şeylerle ilgili sorumluluk alma duygularını geliştirip bilgiyi yapılandırmalarına yardımcı olan becerileridir (Arslan ve Tertemiz, 2004). Bilimsel süreç becerilerin ne olduğuna dair söylenebilecek birçok yol vardır. $\mathrm{Bu}$ yollardan yalnızca birinin doğru olduğunu ileri sürmek yanılgılara sebep olabilir. Bu konuda pek çok yorum vardır (Arslan ve Tertemiz, 2004). Örneğin Lind'e (1998) göre bilimsel süreç becerileri, problemler üzerinde düşünürken elde edilen bilgileri oluşturmak için gerekli görülen sonuçları formüle etmek adına kullandığımız düşünme biçimleridir. Rillero (1998), birey herhangi bir yeteneğini bilimsel bir uğraş için kullanırken verdiği çaba bilimsel süreç becerisi olarak karşımıza çıkar demektedir. Dökme ve Ozansoy (2004), bilimsel uğrașı içerisinde olanların sahip olması gereken birtakım özelliklerin olması gerektiğini söylemektedirler. Bunlar ise gözlem içerisine duyu organlarını katma, gözlem eksenli araştırma, nicel veriler için gözleme başvurma, elde edilen yeni verileri eskisiyle değiştirme şeklinde olması gerektiğini ileri sürmektedirler. Temizyürek (2003) ise doğa olayları kullanılarak bilimsel gerçekleri ortaya çıkarmak için gerekli olan yetenek ve düşünme süreçlerini bilimsel süreç becerileri olarak ileri sürmektedir. Ostlund (1992), bilimsel süreç becerilerini dünyamız hakkında bilgiyi elde etmek ve düzenlemek için sahip olduğumuz en güçlü malzeme olarak tanımlamıştır. Bilimsel süreç becerileri, fen okuryazarlığını kolaylaştırarak bunun için gerekli olan yöntem ve metotların kısa yoldan elde edilmesini sağlamaktadırlar. İyi bir fen okuryazarlığ 1 yaratan bilimsel süreç becerileri öğrencilerin daha çok aktif olmalarına neden olarak öğrenmenin kalıcılığını artıran temel beceriler olarak da kendini göstermektedir (Taşar, Temiz ve Tan, 2002). Pekmez (2000), bilimsel süreç becerilerinin öğrenmeye yardımcı olarak keşfetme duygusunu daha çok ön plana çıkardığını söylemektedir. Bu keşfetme duygusuyla birlikte öğrenciler daha aktif olup pratik çalışma kurallarını daha kısa yoldan anlamalarına yardımcı olacağını da ayrıca belirtmektedir. Bununla birlikte Pekmez, bu becerilerin genelde laboratuvarda kullanıldığı düşüncesinin egemen olduğunu da dile getirmektedir. Harlen (1999) ise bilimsel süreç becerilerinin sadece laboratuvarı değil tüm fen derslerini kapsaması gerektiğini ifade ederek bunun için gerekli firsatların da yaratılması gerektiğini belirmektedir. Üstelik bu becerileri, bireysel öğrenci bazında değerlendirmenin çok da önemli olmadığını ileri sürerek öğrencilerin grupla çalışıp, grupla karar aldıklarında bu becerilerin grup değerlendirmesi ve öğretimin odağını geçtiğini ayrıca belirtmektedir.

Ergin, Şahin ve Öngel (2005), bilimsel süreç becerilerini temel beceriler ve üst düzey beceriler olarak iki kısımda incelemişlerdir. Temel beceriler, daha kompleks üst düzey bilimsel süreç becerilerini öğrenmek için bir öncül olarak kullanılmaktadır (Padilla, 1990).

\subsubsection{Temel Bilimsel Süreç Becerileri}

Temel bilimsel süreç becerileri, bilimsel süreç becerilerinin temelini oluşturan becerilerdir. Bunlar: gözlem yapma, problemi belirleme, sayı-uzay ilişkileri, sınıflama, tahmin, verileri kaydetme ve çıkarım yapmaktır. Bu becerilerin ne anlama geldiği aşağıda kısaca tanımlanmıştır.

\subsubsection{Gözlem Yapma}

Duyu organları yardımıyla herhangi bir objeyi incelemek gözlem yapmak olarak bilinir (Arthur, 1993). İyi bir gözlem yapmak sadece bakmak değil, sistemli olarak da bakmak demektir. Çocuklar çok iyi bir gözlemci olarak bilinir. Öyle ki okula başlamadan kavradıkları birçok şeyi yaptıkları gözlemlere borçludurlar. Çocuklar için gözlem, tüm duyularını kullanıp keşfetme hazzını tatmin etmekten başka bir şey değildir (Blackwell, \& Hofman 1991). Yukarıda da değinildiği gibi gözlem sadece bakmak değil aynı zamanda zihinsel süreçlerin de kullanıldığı aktif bir eylemdir. Öyle ki 
gözlem sonuçları değerlendirilirken elde edilen ilişkili sonuçların, ilişkisiz olandan ayırt eden dinamik bir yapıdır (Harlen, 1993).

\subsubsection{Siniflama Yapma}

Sinıflama genel olarak nesneleri, olay ve olguları açıklayan bilgileri bazı metotlara göre benzer ve farklı özelliklerine göre gruplara ayırma işlemidir (Arthur, 1993). Yapılan bu ayırma işlemi öğrenciler önceki bilgileri ile yeni bilgileri arasında ilişki kurmasını sağlar. Sınıflama rastgele yapılamaz. Bunun için bir metot ya da sistem kullanılması gerekir. Sınıflama yapmanın öğrencilerde açığa çıkan en faydalı yönlerinden birisi kaotik bir yapıya düzen getirmeleridir (Çepni, Ayaz, Johnson ve Turgut 1996).

\subsubsection{3. Ölçme}

Ölçme, yapılan nicel gözlemlerin mevcut değerlerle karşılaştırılmasıdır. Bu karşılaştırma yapılırken geleneksel veya geleneksel olmayan standart değerler dikkate alınır. (Arthur, 1993). Kütle, yoğunluk, hacim, sicaklık, alan gibi ölçülebilir kavramları tanımlamak için standart ve standart dışı birimler kullanılır. Ölçme için deneyim şarttır. Ölçme yeteneği gelişmiş bir öğrenci değişik kavramların özelliklerini ölçerek bunlara ait olan birimleri birbirine dönüştürebilir (Çepni, Ayaz, Johnson ve Turgut 1996).

\subsubsection{Say1-Uzay İlişkileri Kurma}

Sayı ve uzay ilişkileri matematik ile ilgili kurallar, formüller ve nicelikler hakkında bir kanıya varmak için kullanılır. Özellikle uzay ile ilgili olan süreçler objelere ait geometrik şekilleri tanımlamak için ayrılan süreçtir. $\mathrm{Bu}$ geometrik şekillerde objelerin bulunduğu düzlem ve boyutlar daha çok ön plana çıkmaktadır. Bunun için yer ve yön kavramlarının geliştirilmesi bir zorunluluk olarak kendini gösterir. Öğrencilerde sayı-uzay ilişkileri geliştikçe, diğer süreçlerde beraberinde gelişecektir (Çepni, Ayaz, Johnson ve Turgut 1996).

\subsubsection{Tahmin Etme}

Tahmin etme, eldeki verilere dayanarak gelecekte olması muhtemel olaylar hakkında öncül bir kestirimde bulunma işidir. Buradaki kestirim işi rasyonel bir yaklaşımdan uzak bazen hislerin de karıştığ 1 duygusal bir durumdur. Bilimsel çalışmalar tahminlerle yürümektedir. Tahminlerde bulunabilmek için ise deney ve gözlem başvurulması gereken başat iki yöntem olarak karşımıza çıkmaktadır (Esler, 1997).

\subsubsection{Verileri Kaydetme}

Öğrenciler deney yaparken birtakım veriler elde ederler. Veriler bazen niceliksel bazen de niteliksel değerler olabilmektedir. Bu veriler ilk etapta kaotik bir görünüm içerisindedir. Öğrenciler kaotik olan bu veriler kümesini herkesin anlayabileceği formlar şeklinde kaydederler. Verileri faydalı hale getirmek için bu formlar kullanılır (Hughes, \& Wade, 1993). Verileri kaydetme, verileri sonrasında kullanmak ve gerekli modelleri oluşturmak adına elzemdir. Örneğin tablo ya da grafik çizmek isteyen bir öğrenci için kaydedilen bu veriler bir taban oluşturmaktadır (Çepni, Ayaz, Johnson ve Turgut 1996).

\subsubsection{Sonuç Çıkarma}

Sonuç çıkarma, yapılan bir deney ya da gözlem hakkında herhangi bir yargıya varmak durumudur. Sonuç çıkarmak için sahip olunan önceki bilgilerde gereklidir. Sonuç çıkarmayla birlikte öğrenciler verilen bilgilerin ötesinde yeni bilgilerle tanışırlar (Çepni, Ayaz, Johnson ve Turgut 1996).

\subsection{2. Üst Düzey Bilimsel Süreç Becerileri}

Üst düzey bilimsel süreç becerileri temel bilimsel süreç becerilerine nazaran daha karmaşık beceriler olarak karşımıza çıkmaktadır. Öyle ki bu beceriler ile birlikte temel beceriler de kullanıldığından dolayı zihinsel becerilerin daha çok ön plana çıktığı becerilerdir. Üst düzey bilimsel süreç becerileri değişkenleri kontrol etme, hipotez kurma, verileri yorumlama, işlemsel tanımlama ve deney yapma gibi çeşitlerden meydana gelmektedir (Rao, \& Kumari, 2008). Bu becerilerin de ne anlama geldikleri aşağıda kısaca özetlenmiştir.

\subsubsection{Değişkenleri Kontrol Etme}

Bir araştırma için en hayati kısım değişkenlerdir. Araştırmacı değişkenleri belirleyip kontrol ettiği zaman araştırma sorusu daha belirgin bir hal alacaktır (Ramig, Bailer, \& Ramsey, 1995; akt. Aydoğdu, 2014). Değişkenlerin kontrol altına alınması araştırmanın sonucunu etkileyebilecek durumları kontrol altına almak demektir (Abruscato, 2000). Herhangi bir deneyde olası tüm değişkenleri kontrol altına almak zahmetli bir süreçtir. Çünkü bunun için gerekli diğer süreçleri de olayın içine dahil etmek gerekmektedir. Herhangi bir araştırma için değişkenlerin eksiksiz tanımlanması ve belirlenmesi daha iyi sonuçlara ulaşmak için gerekli bir adımdır (Turgut, Baker, Cunningham, Piburn, ve Roger, 1997). Öğrenciler açısından daha sağlıklı deney yapabilmenin ilk adımlarından biri bağımlı, bağımsız ve kontrol değişkenlerini doğru bir şekilde belirlemelerine bağlıdır (Saat, 2004). Padilla (1990), değişkenlerin belirlenip kontrol edilmesini deney sonuçlarını etkileyen değişkenler olarak tanımlamaktadır. Ramig vd. (1995) ise herhangi bir deneyde bir değişkenden daha fazla değişken değiştirilmesi sonuçları ciddi bir biçimde etkileyebileceğini vurgulamışlardır.

\subsubsection{Hipotez Kurma}

Turgut, Baker, Cunningham, Piburn ve Roger (1997), olayların olası açıklamaları ile problemlerin olası çözümlerini hipotez olarak tanımlanmaktadır (Martin, 2003) ise iki değişken arasındaki ilişkiyi en iyi bir şekilde tahmin etme durumuna hipotez demektedir. Ostlund (1992) ise, deney yoluyla test edilebilen problemleri hipotez olarak değerlendirmektedir. Hipotezler kurulurken gözlem ya da çıkarımlara dayanmakla birlikte araştırmanın tasarım şeklini de ortaya koymalıdır (Sittirug, 1997).

\subsubsection{Verileri Yorumlama}

Herhangi bir deneye ait verilerin yorumlanmasıla birlikte birtakım sonuçlar elde edilir. Elde edilen bu sonuçlar verilere ulaşırken ortaya konulan sürecin daha iyi anlaşılmasını sağlar. Bu süreç ise herhangi bir gözleme anlam vermeden hazırlanan tablo, grafik gibi durumlara anlam yüklemedeki değişikliği gösterir (Akdeniz, 2006). Verilerin yorumlaması üzerinde çalışılan araştırma için tahmin yapma, çıkarım yapma ve hipotez kurmayı mümkün kılar. Öğrenciler verileri 
yorumlamadan önce gözlem, sınıflama ve ölçme gibi deneyimlere sahip olması gerekmektedir (Abruscato, 2000). $\mathrm{Bu}$ deneyimler öğrencilerin topladığı verileri daha düzenli hale getirmelerini sağlayacaktır. Veriler yorumlanırken gözden kaçırılmaması gereken șey verilerin dağıtılmasındaki tutumdur. Bu tutum ise duruma karşı kurulan hipotezden kaynaklanmaktadır (Martin, 2003).

\subsubsection{4. İşlemsel Tanımlama}

Bir bilim insanı için en önemli şey değişkenlerin ölçümünü nasıl yapacağına dair karar verme aşamasıdır. Bir değişkeni ölçmek için kullanılan yol işlemsel tanımlama olarak adlandırılır (Ramig, Bailer, \& Ramsey, 1995). Doğrudan ölçülemeyen değişkenleri ya da olayları tanımlamak için işlemsel tanımlamalar kullanılır (Martin, 2003). Bu anlamda işlemsel tanımlama bir ölçmenin hayata geçirilme yolunu gösterir. Bilim insanı belirlediği yöntemi diğer meslektaşlarının test etmesine izin vermelidir (Ramig vd., 1995). Öğrenciler işlemsel tanımlama sürecini gerçekleştirirken üzerinde çalıştıkları deneyle ilgili terimleri tespit ederler. Böylece terimleri ezberlemek yerine onları açıklama gayretine girişirler (Abruscato, 2000).

\subsubsection{Deney Yapma}

Bir deney yapma süreci, hem temel hem de üst düzey becerileri gerektiren kaotik bir süreç olarak karşımıza çıkmaktadır (Sittirug, 1997). Deney yapmak, genel olarak sorulara yanıt arayan gözlemle başlar. Bazen öğrenciler, sorulardan yola çıkarak bir hipotez ortaya koyarlar (Abruscato, 2000). Öğrenciler uygun bir deney yapmak adına aşağıda belirtilen yedi temel maddeyi hayata geçirmeleri gerekmektedir (Germann, Aram, \& Burke, 1996). Bu maddeler sirasiyla:

a) Bağımsız değişkeni nasıl kurmalıyız,

b) Bağımsız değişken nasıl manipüle edilmeliyiz,

c) Bağımlı değişken nasıl gözlemeliyiz ya da ölçülmeliyiz,

d) Hangi değişken sabit tutmalıyız,

e) Yapılması gereken denemelerin sayısı kaç olmalı,

f) Deneysel bir kontrol sağlanmalı mi?

g) Deney tasarlanırken, öğrencilerin hipotezlerini test edip etmediklerini kontrol edilmesi şeklinde sıralanmaktadır.

Yukarıda açıklamaya çalıştığımız temel ve üst düzey bilimsel süreç becerilerinin verilmesi gereken yerler tabii ki eğitim kurumlarıdır. Öyle ki ismini andığımız bu kurumlar sağlıklı bir bilimsel süreç beceri eğitimi ile insanın çağını ve geleceğini yakalamasına yardımcı olabilir. Bunun yanı sıra insanca yaşamak için gerekli olan olanak ve desteği de vererek kendini daha çok ön plana çıkarabilir. Özellikle bilimi, amaç ve işlev boyutunda toplumlara götürecekleri hizmet çerçevesinde karma bir çalışma sergileyip insan davranışlarını geliştirip zenginleştirerek insanı daha üretken duruma getirebilir (Arslan ve Tertemiz, 2004). Gerek düşünsel gerekse üretkenlik açısından insanın gelişimini amaçlayan eleştirel pedagoji, dogmaları reddetmeyip dönüştürmeyi arzulamaktadır. Özellikle bilimsel düşünme becerilerini ön plana çıkararak koşulsuz kontrole karşı daha sağlıklı bir davranış sergilemeyi hedeflemektedir.

\subsection{Eleştirel Pedagoji}

İnsan sürekli evrilen ve bununla da baş edemeyen bir varlık olduğunu dikkate aldığımızda, insanı tanımlamaya çalışan geleneksel pedagojinin neden eksik kaldığını anlayabiliriz.
İnsanı kendi hedefleri doğrultusunda değiştirmeyi amaçlayan geleneksel pedagoji ve buna bağlı mevcut öğretim programlarının temel yaklaşımı davranışçı yaklaşım ekseninde dönmektedir. Öyle ki eğitimin tanımını ve uygulamasını bu argümanı dikkate alarak yapmaya çalışmaktadır. Bu pedagojiye göre eğitim, uygulayıcıları tarafından bireyde istedikleri şekilde davranış sergileme süreci olarak tanımlanmaktadır. Yani eğitim, bireyde istendik davranış değiştirme süreci olarak değerlendirilmektedir. Fakat bu eğitim yaklaşımının öğrencileri eleştirel düşünme gücünden yoksun bıraktığı düşünülmektedir. Bu anlayışta asıl sorgulanan şey, davranış değişliklerini kimin istediği ve biçimlendirmek kelimesinin altında yatan anlamdır (Y1lmaz ve Altınkurt, 2011). Örnek vermek gerekirse okulsuz toplumu savunan Illich (2009) ve zorunlu eğitime karşı çıkan Baker (2006) okulların belli çıkarlara sahip kişilerin bireylerde ahlak ve din şekillendirmelerinin yapıldı $\breve{g}_{1}$ yerler olduğunu ileri sürmektedirler. $\mathrm{Bu}$ nokta özellikle özgürleştirici eğitimi savunanlar tarafından sürekli tartışılan önemli konulardan biridir. Özgürlükçü eğitimcilere göre devlete bağlı okullar ve buralarda kullanılan eğitim programları kendini ifade edemeyen, içine kapanık, öz güvenlerini kaybetmiş ve itaat kültürüyle yetişen bireyler ortaya çıkardığını ileri sürmektedirler (Chomsky, 2007). Buna karşı eğitim şekil vermekten ziyade özgürleştirmenin aracı olmalıdır. Bu anlamda özgürleştirici pedagoji kuramcıları eğitimi, insanlaşma ve özgürleşmenin bir aracı olarak görmektedir. Özgürleştirici pedagoji olarak sınıflanan akımlardan biri de eleştirel pedagojidir (Yılmaz ve Altınkurt, 2011).

Eleştirel pedagojiyi genel olarak eğitimden kaynaklı sorunları gündeme getiren bir eğitim yorumu olarak da düşünebiliriz (Yılmaz ve Altınkurt, 2011). Eleştirel pedagoji, mevcut eğitim tanımlarını yeniden ele alıp, farklı tanımlamalarla yeni bir eğitim yorumu inşa etmeye çalışır. $\mathrm{Bu}$ inşa sürecinde eleştirel pedagoji şu sorulara cevap vermeye çalışır: 1- Eğitim içerisinde yaptığımız şeyleri neden yapıyoruz? 2- Neden alışagelmiş klasik veya geleneksel anlayış ile bunları yapıyoruz? 3- Devlet eğitim verirken gözettiği asıl amaç nedir? (Giroux, 2009). McLaren'e (1993) göre okul gibi eğitim kurumlarını sadece bir eğitim alanı olarak değil, aynı zaman da öğrencileri yetkilendirmeye ve kendi kendilerini dönüştürmeye teşvik eden kültürel bir alan olarak da görülmesi gerektiğini söyler. Eleştirel pedagoji, eğitim ve siyaset ile eğitsel pratikleri, gündelik hayatta ve dersliklerde iktidar ilişkilerinin yeniden üretilmesi arasındaki ilişkinin sorgulanması gerektiğini ileri sürer (Fischman, \& Maclaren, 2005). Bunun yanı sira eleştirel pedagoji okullardaki müfredatın bilgiyi iktidardan soyutlayıp teknik açıdan ele alarak bilginin belirli çıkarlarla ve toplumsal ilişkilerle bağlantılı bir ideolojik inşa olmaması gerektiğini de ayrıca ileri sürer. Bunun yanı sıra eleştirel kuram, okulda edinilen bilginin asla nesnel ya da tarafsız olmadığını, belirli biçimlerde düzenlenip yapılandırıldığını da belirtir (McLaren, 2003). Althusser'e (1991) göre okul ve buna bağlı eğitim, etki alanı geniş en güçlü ideolojik bir aygıttır. Bu aygıt sahip olduğu ideolojik yaklaşımları öğretmen, kitap ve öğretim programları ile öğrencilere sunarak hâkim paradigmanın değerlerini olumlayıp bu paradigmayı destekleyen kişilerin politikalarına eşlik eder. Eğitim, iktidar ile ideolojinin uzlaşma alanı olup aynı zaman da bireylerin dönüşümlerini şekillendirmede de bir role sahiptir (Apple, 2004). Bu şekillendirmeyi ise sahip olduğu 
öğretim programları aracılığı ile yapıp, bireyleri tek tip ve istendik değerlere sahip ilkel prototiplere dönüştürür. Bu prototiplerin ortaya çıkmasına neden olan şey ise öğretim programlarını belirleyen piyasa ve liberal ekonomi politikalarıdır (Apple, 2011).

Eleştirel pedagoji, özgürlüğü getirebilmek adına eğitimi siyasal bir eylem olarak da ele almaktadır (Freire, 2010). Bu bakımdan eleştirel pedagojinin sürekli gündeme getirdiği iki şey kapitalizm ve neo-liberal ekonomi politikalarıdır. Bu politikaların eşitsizlik temeline dayandığ 1 ve özellikle de devlet okulları aracılığı ile uyuşmuş beyinler yaratarak kendi geleceklerini sürdürme gayreti içerisinde olduklarını belirtmektedir (Yılmaz ve Altınkurt, 2011). Küreselleşmeci ve neo-liberal politikalarla eğitim metalaşmış, satılık pahalı bir mal haline gelmiş; eğitim kurumları işletme zihniyetiyle planlamaya başlamıştır (İnal, 2010). Bu anlayış çerçevesinde devlet kendi vatandaşını sıradan bir tüketici, dünyayı ise büyük bir süpermarket olarak görmektedir (Apple, 1982). Aynı mantık içerisinde Giroux (2009) ise, vatandaşlık ile piyasa aynı mantık içinde değerlendirildiği, gençlerin ise düşünen ve eleştiren öznelerden ziyade tüketen birer öznelere dönüştüğünü ifade etmektedir. Böyle bir sistem içerisinde ise doğal olarak eğitim alınıp satılabilen bir ticaret nesnesine haline getirilmektedir (Apple, 2009).

Eleştirel pedagoji ilkelerine göre hareket eden bir eğitimci içgüdüsel olarak özgürlükçü eğitimci kimliğini sergileyecektir (Freire, 2009). Yılmaz ve Altınkurt (2011), hem gelenekçi hem de özgürlükçü pedagojide temel amacın bireylere yetkinlik ve beceriler kazandırmak olduğunu ileri sürmektedirler. Fakat gelenekçi eğitimci sistem konumları dikkate alarak bunu yaparken özgürlükçü eğitimci ise öğrenci beklentilerini dikkate alarak bunları gerçekleştirmeye çalışmaktadır (Freire, 2009). Özgürlükçü eğitimci bireylerin kişisel özerlik, kendini tanıma, kendini gerçekleştirme, öz yönetim ve denetim, kendine güven ve kişiliğin çok yönlü gelişmesi gibi kavramlara daha çok vurgu yapmaktadır. Bunun yanı sıra çalışmanın ekonomik olmasının yanı sıra toplumsal, kültürel ve eğitimsel özellikleri açısından da önemli olduğunu vurgular. Ayrıca eleştirel eğitimci, bireyi, çok yönlü ve özerk gelişmesini sağlayacak ve kendi yazgısını belirleyebilecek yeterliliklerle donatacak biçimde yetiştirilmesi gerektiğini de ayrıca vurgular (Özsoy, 2004).

Öğretmen ve öğrenci ilişkileri açısından mevcut öğretim programları (halihazırda uygulanan) ile eleştirel programlar arasında önemli farklar bulunmaktadır. Mevcut öğretim programları, güç ve iktidar ilişkilerinin bir yansıması şeklinde kendini göstererek eğitim ortamında hiyerarşik bir sıralama getirmektedir. Mevcut öğretim programlarında öğrenciler kendilerine sunulan bilgileri çok fazla sorgulamadan aynen kabul ederler. Başka bir deyiş ile eleştirel yeteneklerinin geliştirilmesine çok fazla izin verilmemektedir (Y1lmaz ve Altınkurt, 2011). Freire (2010), böyle bir modelden kaynaklanan eğitim sisteminin daha çok ezberci bir eğitim sitemi olduğunu ileri sürmektedir. Böyle bir sistemde daha çok öğrenciler öğretmenler tarafindan doldurulması gereken boş kaplar olarak görülmektedir. Öğretmen kapları ne kadar çok doldurursa o kadar iyi öğretmendir. Kaplarda dolmaktan şikâyet etmiyorlarsa o kadar iyi öğrencilerdir. Freire (2010) bu şekildeki eğitimi "bankacı eğitim modeli" olarak tanımlamaktadır. Böyle bir sistemde eğitim tasarruf yatırımı, öğrenciler yatırım nesneleri öğretmenler ise yatırımcı olarak dile getirilmektedir.

Bankacı eğitim modeli insanların etki altına alınacak varlıklar olarak değerlendirir. $\mathrm{Bu}$ modelde öğrenciler kendilerine sunulan bilgileri ezberlemekle meşgul oldukları için eleştirel düşünme yeteneklerini de kaybetmektedirler (Y1lmaz ve Altınkurt, 2011).

Yaratıcılığı engelleyen bankacı eğitim modelinin aksine eleştirel pedagojik yaklaşım ise, öğrenciyi bir bilme ve yaratma eylemi olarak okuma ve yazmayı öğrenme sürecinin öznesi olarak görür (Freire, 1998). Eleştirel pedagojik yaklaşımda temel kavram “diyalog” dur. Freire'ye (2006) göre diyalog varoluşsal bir gerekliliktir. Kendimizi başkalarıyla diyalog aracılığıyla insanlaştırırız (Roberts, 2003). Diyaloğun insanlaştıran bir Praksis'e dönüşmesi için ise eleştirel düşünme olmazsa olmazdır (Sağıroğlu, 2013). Freire'ye (2006) göre diyalog, bu eylemi gerçekleştiren kişilerin düşünce ve kaygılarının buluştuğu bir platformdur. $\mathrm{Bu}$ anlamda diyalog, sadece fikirlerin sunulup değiş tokuş edildiği sıradan bir eylem olarak düşünülemez. Diyalog, diyalogcuların kendi fikirlerini sunarken biçimlendiği ve değiştiği diyalektik bir dinamizmi ifade eder (Berthoff, 1998). Eleştirel yaklaşım, “öğrencilerin öğretmeni” ve “öğretmenin öğrencileri” kavramlarını ortadan kaldırarak yeni bir akımın ortaya çıkmasına neden olmuştur. Bu akımda öğretmenler sadece öğreten, öğrenciler ise sadece dinleyen olmaktan çıkıp eğitim, öğretmenin ve öğrencilerin aynı anda hem öğrendiği hem öğrettiği bir süreç haline gelmektedir. Bu süreçte öğrenciler uysal dinleyiciler olmaktan çıkarak öğretmenle diyalog içinde eleştirel araştırma ortaklarına dönüşürler. Öğretmen öğrencilere malzemeyi sunar ve bu malzeme üzerinde düşünüp yorumlarını dile getirirken öğretmen de önceki değerlendirmelerini gözden geçirir (Freire, 2006).

$\mathrm{Bu}$ çalışma geleneksel pedagojiden uzak kalmak şartıyla eleştirel pedagojinin ilkeleri dikkate alındığında öğrencilerin bilimsel süreç becerilerinde meydan gelebilecek değişimleri açığa çıkarmayı amaçlamıştır. $\mathrm{Bu}$ amaç doğrultusunda çalışma boyunca aşağıda verilen sorulara cevap aranmıştır.

1. Eleştirel pedagoji ilkelerine göre yapılan fen öğretiminin öğrencilerin bilimsel süreç becerilerine olan etkisi nedir?

2. Eleştirel pedagoji ilkelerine göre fen öğretimi yapıldığında en çok etkilenen bilimsel süreç becerileri nelerdir?

\section{Yöntem}

$\mathrm{Bu}$ başlık altında araştırmanın modeli, çalışılan grubun ve veri toplama araçlarının nelerden meydana geldiğinden bahsedilmiştir. Bunun yanı sıra veri toplama araçlarından olan bilimsel süreç beceri testi ve öğrenciler tarafindan hazırlanan fen bilimleri öğretim programı da yine bu başlık altında incelenmiştir.

\subsection{Araştırmanın Modeli}

$\mathrm{Bu}$ çalışma nicel yöntemlerin kullanıldığı bir çalışmadır. Araştırma eleştirel pedagoji ilkelerine göre yapılan fen öğretiminin öğrencilerin bilimsel süreç becerilerinde meydana getirecek değişimleri belirlemek adına yarı deneysel yöntemlerden eşdeğer olmayan karşılaştırma grubu deseni kullanılarak gerçekleştirilmiştir (Christensen, Jonson, \& Turner, 2015). Eşdeğer olmayan karşılaştırma grup deseni yarı deneysel desenler içinde en fazla kullanılan araştırma 
modelidir. $\mathrm{Bu}$ desen hem deney hem de karşılaştırma grubundan oluşur. Fakat katılımcılar yansız atanmazlar. Yansız atama olmadığından dolayı kontrol ve deney grubundaki katılımcılar birçok değişken açısından eşdeğer olmayacaklar ve bu durum bağımlı değişkenleri etkileyecektir. Kontrol edilmeyen değişkenler, bu deseni yarı deneysel desen yaparak deneyin sonuçlarını açıklayan alternatif hipotez işlevinde bulunur. Eşdeğer olmayan karşılaștırma grubu deseninde iki grubun ön ve son testleri arasında önemli farklar oluşup oluşmadığını belirlemek için karşılaştırılır. $\mathrm{Bu}$ anlamda eşdeğer olmayan karşılaştırma grubu deseni eşdeğer olmayan gruplarla sadece son test desenin daha gelişmiş bir çeşididir (Christensen, Jonson, \& Turner 2015).

Eleştirel pedagoji ilkelerine göre yapılan fen öğretiminin öğrencilerin bilimsel süreç becerilerine olan etkisini araştırmak için uygulama sürecinde iki kez bilimsel süreç becerileri testi uygulanmıştır. Bunun yanı sıra eleştirel pedagoji ilkelerinden olan özgür öğretim programı görmek adına öğrencilere kendi beklentileri doğrultusunda fen bilimleri öğretim programı hazırlama firsatı verilmiştir. Mevcut fen bilimleri öğretim programı ile öğrencilerin hazırladıkları fen bilimleri öğretim programı karşılaştırılıp bir liste olarak sunulmuştur.

\section{2. Çalıșma Grubu}

Araştırmanın çalışma grubunu Doğu Anadolu'da bir ile bağlı ilçedeki devlet okulunda beş farklı şubede öğrenin gören 129 sekizinci sınıf öğrencisi oluşturmaktadır. Araştırmaya konu olan katılımcılar benzer sosyo-ekonomik özelliklere sahip olmakla birlikte öğrenim hayatlarını devlet okulunda geçiren ve benzer fen bilimleri öğretim programına tabi olan 75 erkek ve $44 \mathrm{k1z}$ öğrenciden meydan gelmektedir. Bu öğrencilerin öğrenim gördükleri sınıflara göre dağılımı ve cinsiyetleri Tablo'1 de verilmiştir. 8/A ve 8/B sınıfları deney grubu olarak alınıp diğer şubeler kontrol grubu olarak dikkate alınmıştır. Ön test anlamında yapılan bilimsel süreç becerileri testi sonucunda gruplar arasında anlamlı bir fark olmadığından dolayı tüm şubeler başlangıçta eşit varsayılmış ve deney grupları rastgele seçilmiştir.

Tablo 1. Öğrencilerin Şubelere Göre Dağılımı

\begin{tabular}{cccc}
\hline Şubeler & Erkek & Kiz & Öğrenci sayı1 1 \\
\hline 8/A & 12 & 8 & 20 \\
\hline 8/B & 13 & 12 & 25 \\
\hline 8/C & 14 & 11 & 25 \\
\hline 8/D & 20 & 15 & 35 \\
\hline 8/E & 16 & 8 & 24 \\
\hline TOPLAM & 75 & 54 & 129 \\
\hline
\end{tabular}

Tablo 1, çalışmaya katılan öğrencilerin şubelere göre erkek ve kız öğrenciler açısından toplam sayılarını göstermektedir. Aynı zamanda çalışmaya katılan şubelerin karma bir görünüm sergilediğini göstermekle beraber sınıflar bazında heterojen dağılımını da göstermektedir. Bu anlamda 8/A sinıf 12 erkek ve $8 \mathrm{k} 1 \mathrm{z}, 8 / \mathrm{B}$ sinıfı 13 erkek ve $12 \mathrm{k} 1 \mathrm{z}, 8 / \mathrm{C}$ sinıfi 14 erkek ve $11 \mathrm{k} 1 \mathrm{z}, 8 / \mathrm{D}$ sinıfi 20 erkek ve $15 \mathrm{kız}, 8 / \mathrm{E}$ sınıfı 16 erkek ve 8 kız öğrenciden meydana gelmektedir.

\subsection{Veri Toplama Araçları}

$\mathrm{Bu}$ başlık adı altında araştırmada kullanılan veri toplama araçlarına dair açıklamalarda bulunulmuştur.

\subsubsection{Bilimsel Süreç Becerileri Testi}

Eleştirel Pedagoji İlkelerine göre yapılan fen öğretiminin öğrencilerin bilimsel süreç becerilerine olan etkisini ölçmek adına Aydoğdu ve diğerleri (2012) tarafından geliştirilen "Bilimsel Süreç Becerileri Testi” kullanılmıştır.

\subsubsection{Bilimsel Süreç Becerileri Testi}

Bilimsel Süreç Becerileri Testi, Aydoğdu ve arkadaşları tarafından altı, yedi ve sekizinci sınıf öğrencilerine yönelik olarak geliştirilmiştir. Test toplamda 27 çoktan seçmeli sorudan meydana gelip güvenirlik katsayısı (KR-20) 0.84 , ortalama güçlüğü ise 0.54 olarak elde edilmiştir. Testin $\% 27$ ve alt \%27 dilimde yer alan öğrencileri ayırt edip etmediğini belirlemek için ise üst $\% 27$ ve alt $\% 27$ dilimde yer alan ögrencilerin ortalama puanları arasındaki farklar her bir madde için incelenmiş ve elde edilen sonuçlardan, farkların her bir madde için istatiksel olarak anlamlı $(\mathrm{p}<0.05)$ olduğu elde edilmiştir. Geliştirilen testteki 27 sorunun, üst ve alt grupta yer alan öğrencileri ayırt ettiği tespit edilmiştir.

Aydoğdu ve arkadaşları tarafından geliştirilen bilimsel süreç becerileri testi, temel ve üst becerileri ölçen sorulardan oluşmaktadır. Testte, temel becerilerden gözlem yapma, sınıflama yapma, sayı- uzay ilişkilerini kullanma, tahmin yapma, çıkarım yapma becerilerine yönelik sorular yer alırken üst düzey becerilerden problem belirleme, hipotez kurma, değişkenleri belirleme ve kontrol etme, deney yapma ve verileri yorumlama becerilerine yönelik sorular yer almaktadır. Test, temel becerilere ait dokuz soru ve üst düzey becerilere ait 18 sorudan oluşmaktadır.

\subsubsection{2. Öğrenciler Tarafindan Hazırlanan Fen Bilimleri Öğretim Programı}

Deney grubundaki fen bilimleri dersi eleştirel pedagoji ilkelerinden olan özgür programlar hazırlama ilkesinden hareketle öğrenciler tarafından hazırlanıp dersler bu programa göre işlenmiştir. Öğrenciler tarafından hazırlanan fen bilimleri öğretim programındaki kazanım ve ders saatleri yine kendileri tarafindan belirlenip mevcut fen bilimleri öğretim programındaki kazanım ve ders saatlerine göre değerlendirilmesi aşağıdaki tabloda verildiği gibidir.

Tablo 2. Mevcut Fen Bilimleri Öğretim Programındaki Kazanım ve Ders Saatleri Sayıs

\begin{tabular}{llccc}
\hline \multicolumn{1}{c}{ Ünite adı } & Konu alanı & $\begin{array}{c}\text { Kazanım } \\
\text { sayısı }\end{array}$ & $\begin{array}{c}\text { Ders } \\
\text { saati }\end{array}$ & $\begin{array}{c}\text { Yüzde } \\
(\%)\end{array}$ \\
\hline Mevsimler ve İklim & $\begin{array}{l}\text { Dünya ve } \\
\text { Evren }\end{array}$ & 3 & 14 & 9.7 \\
$\begin{array}{l}\text { DNA ve Genetik } \\
\text { Kod }\end{array}$ & $\begin{array}{l}\text { Canlılar ve } \\
\text { Yaşam }\end{array}$ & 13 & 22 & 15.3 \\
Basınç & $\begin{array}{l}\text { Fiziksel Olaylar } \\
\text { Madde ve Endüstri }\end{array}$ & 3 & 10 & 6.9 \\
Madde ve & Doğası & 17 & 28 & 19.4 \\
Basit Makineler & Fiziksel Olaylar & 2 & 10 & 6.9 \\
$\begin{array}{l}\text { Enerji Dönüşümleri } \\
\text { ve Çevre Bilimi }\end{array}$ & Canlılar ve & 12 & 24 & 16.4 \\
$\begin{array}{l}\text { Ylektrik Yükleri ve } \\
\text { Elektrik Enerjisi }\end{array}$ & Fiziksel Olaylar & 11 & 24 & 16.7 \\
$\begin{array}{l}\text { Fen ve Mühendislik } \\
\text { Uygulamaları }\end{array}$ & Yıl Sonu Bilim & --- & 12 & 8.3 \\
Toplam & & 61 & 144 & 100 \\
\hline
\end{tabular}

Tablo 2, mevcut yani hali hazırda uygulanan fen bilimleri öğretim programındaki ünite isimleri ile konu alanlarını göstermekle birlikte bu konulardaki kazanım sayılarının 
uygulanması gereken ders saati ve yüzdelik dilimlerine de işaret etmektedir. Tablo 2'ye bakıldığında Millî Eğitim Bakanlığı tarafından hazırlanan fen bilimleri öğretim programında toplam 61 kazanım sayısı için ayrılan toplam ders saatinin 144 olarak değerlendirildiği görülmektedir. Konu alanları içerisinde özellikle madde ve doğası, canlılar ve yaşam ile fiziksel olayların yüzdelik paylarının daha çok olduğu dikkat çekmektedir.

Tablo 3. Öğrenciler Tarafından Hazırlanan Fen Bilimleri Öğretim Programındaki Kazanım ve Ders Saatleri Sayısı

\begin{tabular}{|c|c|c|c|c|}
\hline Ünite ad 1 & Konu alanı & $\begin{array}{c}\text { Kazanım } \\
\text { sayıs1 }\end{array}$ & $\begin{array}{l}\text { Ders } \\
\text { saati }\end{array}$ & $\begin{array}{c}\text { Yüzde } \\
(\%)\end{array}$ \\
\hline Basit Makineler & Fiziksel Olaylar & 5 & 12 & 10.5 \\
\hline Basınç & Fiziksel Olaylar & 6 & 12 & 10.5 \\
\hline $\begin{array}{l}\text { Elektrik Yükleri } \\
\text { ve Elektrik } \\
\text { Enerjisi }\end{array}$ & Fiziksel Olaylar & 10 & 24 & 20.9 \\
\hline $\begin{array}{l}\text { DNA ve Genetik } \\
\text { Kod }\end{array}$ & $\begin{array}{l}\text { Canlılar ve } \\
\text { Yaşam }\end{array}$ & 17 & 24 & 20.9 \\
\hline $\begin{array}{l}\text { Enerji } \\
\text { Dönüşümleri ve } \\
\text { Çevre Bilimi }\end{array}$ & $\begin{array}{l}\text { Canlılar ve } \\
\text { Yaşam }\end{array}$ & 11 & 18 & 15.6 \\
\hline $\begin{array}{l}\text { Mevsimler ve } \\
\text { İklim }\end{array}$ & Dünya ve Evren & 2 & 10 & 8.6 \\
\hline $\begin{array}{l}\text { Madde ve } \\
\text { Endüstri }\end{array}$ & Madde ve Doğas 1 & 10 & 15 & 16.7 \\
\hline Toplam & & 61 & 115 & 100 \\
\hline
\end{tabular}

Tablo 3 ise bizzat öğrenciler tarafindan hazırlanan ünite, konu alanı, kazanım sayısı, ders sayısı ile konuların ünitelere göre yüzdelik dilimlerini göstermektedir. Tablo 3'ü değerlendirdiğimizde öğrencilerin bakanlığın öğretim programından farklı olarak DNA ve genetik kod, enerji dönüşümleri ve çevre bilimi, basit makineler ile basınç ünitelerini daha çok ön plana çıkardıklarını görmekteyiz. Öyle ki öğrenciler fiziksel olaylar konu alanına toplamda 48, canlılar ve yaşam konu alanına ise 42 saat ders ayarlamışlardır. En düşük ders saatini ise Dünya ve Evren konusuna vermişlerdir. Bu ders hesaplamaları ise tamamıyla öğrencilerin kendi beklentileri doğrultusunda gerçekleşmiştir.

\subsection{Verilerin Toplanmas1}

Uygulamalar sekizinci sınıf fen bilimleri dersinde yürütülmüştür. Uygulamalar 24 hafta boyunca haftada dört saat süresince yapılmıştır. Deney grubundaki dersler araştırmacı tarafından işlenirken kontrol grubundaki dersler araştırmanın yapıldığ 1 okuldaki diğer fen bilimleri öğretmenleri tarafından yapılmıştır. Deney grubundaki uygulamaları yapan öğretmen araştırmacının kendisi olup 24 yıllık fen bilimleri öğretmenidir.

Araştırmada kontrol grubundaki öğrencilere mevcut yani halihazırda uygulanan fen bilimleri programına göre dersler işlenmiş, deney grubundaki öğrencilere ise öğrencilerin kendileri tarafından hazırlanan fen bilimleri öğretim programı dikkate alınarak dersler işlenmiştir. Kontrol grubundaki öğrenciler mevcut fen bilimleri öğretim programının belirlemiş olduğu etkinlikleri yaparken, deney grubu öğrencileri yine kendileri tarafindan belirlenen etkinlikleri yapmışlardır. $\mathrm{Bu}$ etkinlikler sınıf içi ve laboratuvar etkinliklerinden oluşup öğrencilerin belirlediği saatler içerisinde gerçekleştirilmiştir.
Araştırma boyunca kontrol grubu öğrencileri sınıf rehber öğretmenlerinin belirlediği oturma düzenlerine göre sınıf içi ve laboratuvar pozisyonlarını belirlerken, deney grubundaki öğrencilerde bu durum tamamiyla öğrencilerin kendi tercihleri doğrultusunda gerçekleşmiştir. Öyle ki bu oturma düzenleri bazı haftalarda u bazı haftalarda ise klasik oturma düzeni olarak gerçekleşmiştir.

Araştırma başlangıcında deney grubu öğrencilerine mevcut fen bilimleri öğretim programı içeriğinden bahsedilmiş, istemeleri halinde bu içeriği kendi beklentileri doğrultusunda değiştirebilecekleri vurgulanmıştır. Bu şekilde araştırmacı tarafından eleştirel pedagoji ilkelerine sadık kalınmak şartıyla öğrencilerde özgüven oluşumunu ortaya çıkarmak, sosyal hayat ile ilintili üniteleri daha çok dikkate almalarını sağlamak ve en önemlisi öğrencilerin hem ders hem de materyallere karşı eleştirel yaklaşım becerilerini geliştirmeleri hedeflenmiştir. Bu doğrultuda gerek fen bilimleri dersi gerekse deneyler mümkün mertebe deney grubundaki öğrencilerin bizzat kendileri tarafından işlenmiş ve yapılmıştır. Deney grubundaki öğrenciler dersleri işlerken ve deneyleri yaparken açığa çıkan sonuçlar açsından diğer arkadaşlarının eleştirel yaklaşımlarına fırsat tanıyabilme adına demokratik bir ortam sağlamışlardır. Ayrıca ders süreleri ve dinleme araları ise yine deney grubundaki öğrenciler kendi aralarında tartışarak karar vermişlerdir.

Araştırma başlangıcında ve bitiminde deney ve kontrol gurubu öğrencilerine bilimsel süreç beceri testi uygulanıp sonuçlar değerlendirilmiştir. Bilimsel süreç beceri testi toplamda 27 çoktan seçmeli sorudan meydan gelmektedir. Fakat uygulama esnasında deney grubu öğrencilerinin kendi hazırladıkları fen bilimleri öğretim programı dikkate alındığından dolayı yaptıkları etkinlik ve deney türlerine göre soru sayısı 19 düşürülmüştür. Kapsam geçerliliği bakımından uzman görüşü alındıktan sonra 19 soruluk ön deneme testi oluşturulup 27 öğrenciye uygulanarak testin pilot çalışması yapılmıştır. Testin güvenirlik çalışması pilot uygulama esnasında yapılmış olup, $0,60 \leq \alpha \leq 0,80$ aralığında olduğu tespit edilmiştir.

Testte yer alan temel becerilerden gözlem yapma (2), sınıflama yapma (2), sayı- uzay ilişkileri (2) sorudan oluşurken üst düzey becerilerden verileri yorumlama (2), deney yapma (5), hipotez (4) ve problemi belirleme (2) sorudan meydana gelmektedir. Bilimsel süreç beceri testinde yer alan soru ve sayıları aşağıdaki tabloda gösterilmiştir.

Tablo 4. Bilimsel Süreç Beceri Testinde Yer Alan Becerilerin Sayısı ve Testteki Soru Numaraları

\begin{tabular}{|c|c|c|c|}
\hline $\begin{array}{c}\text { Bilimsel Süreç } \\
\text { Becerileri }\end{array}$ & Beceri Alt Boyutu & $\begin{array}{l}\text { Beceri } \\
\text { Sayıs1 }\end{array}$ & $\begin{array}{c}\text { Testteki Soru } \\
\text { Numarası }\end{array}$ \\
\hline \multirow{4}{*}{$\begin{array}{l}\text { Temel } \\
\text { Beceriler }\end{array}$} & Gözlem yapma & 2 & 1,2 \\
\hline & Sinıflama yapma & 2 & 3,4 \\
\hline & Sayı-uzay ilişkileri & 2 & 5,6 \\
\hline & Verileri yorumlama & 2 & 7,8 \\
\hline \multirow{3}{*}{$\begin{array}{l}\text { Üst Düzey } \\
\text { Beceriler }\end{array}$} & Deney yapma & 5 & $9,10,11,12,13$ \\
\hline & Hipotez kurma & 4 & $14,15,16,17$ \\
\hline & Problemi belirleme & 2 & 18,19 \\
\hline
\end{tabular}

Tablo 4, bilimsel süreç becerilerini görmek adına kullanılması uygun görülen bilimsel süreç beceri testindeki becerilerin sayısı ve bu testteki sira numarasını göstermektedir. Tablo 4, öğrencilerin yaptığı fen bilimleri öğretim programına göre bilimsel süreç beceri testinde yer 
alacak becerilerin sayısını da göstermektedir. Bu anlamda üst düzey becerileri görmek adına deney ve hipotez kurma becerilerine ait sorulara daha fazla yer verilmiştir. Diğer becerilere ait soru sayısı 2 ile sınırlandırılırken bahsi geçen beceriler 5 ve 4 tane sorudan oluşmaktadır.

\subsection{Verilerin Analizi}

Elde elden veriler SPSS 20.00 paket programiyla analiz edilmiştir. $\mathrm{Bu}$ analizlerde, öncelikli olarak istatistikler hesaplanmış ve dağılımın özellikleri ortaya konulmuştur. Araştırmada kullanılan bilimsel süreç becerileri testindeki her bir soru için öğrencilerin verdikleri doğru cevaplar 1, yanlış cevaplar ise 0 olarak puanlanmıştır. Bu nedenle ölçme aracı, araştırmacı tarafından "test" olarak nitelendirilmiştir. Dolayısıyla araştırmaya katılan öğrencilerin maksimum puan 19, minimum puan ise 0 olmuştur. Yapılan bu puanlamalar neticesinde anlamlı farklılık düzeyi, varyans analizi kullanılarak, $p<0,05$ düzeyinde test edilmiş ve gerekli durumlarda da post-hoc test olarak Tukey testi uygulanmıştır. İki değişkenli özelliklerin ortalamaları arasında anlamlı bir şekilde farklılık olup olmadığını test etmek için Bağımlı Gruplar T-Testine başvurulmuş, ikiden fazla değişkenli özellikler açısından ise Tek Faktörlü Varyans Analizi (ANOVA) uygulanmıştır. Tek faktörlü Varyans Analizi (ANOVA) normal dağılımlı bir seride üç veya daha fazla bağımsız ortalama arasındaki farkın manidarlığının hesaplanmasında kullanılır. ANOVA, tek başına üç veya daha fazla grubun aritmetik ortalamalarını kümülatif olarak karşılaştırır; bu karşılaştırmalardan birisi anlamlı olduğunda ANOVA sonucu da anlamlı bulunur (Kalayc1, 2010).

\section{Bulgular}

$\mathrm{Bu}$ başlık adı altında SPSS, sonuçları tablolaştırılıp yorumlanmıştır. Öncelikli olarak deney ve kontrol gruplarına uygulana bilimsel süreç beceri testinin betimsel istatistikleri olan ortalama ve standart sapma değerleri verilerek öğrencilerin bilimsel süreç beceri testindeki ortalamalarının kontrol grubuna göre farklı olup olmadığ tespit edilip yorumlanmıştır. Daha sonra grupların ortalamaları arasında anlamlı bir fark olup olmadığını anlamak için Tek Faktörlü Varyans (ANOVA) testi uygulanıp yorumlanmıştır. Hangi grupların ortalamaları arasında anlamlı fark olduğunu tespit etmek için ise post-hoc testi olarak Tukey HSD çoklu karşılaştırma testine başvurulup yorumlanmıştır. Son olarak ise eleştirel pedagoji ilkelerine göre yapılan fen öğretiminde en çok etkilenen bilimsel süreç becerilerini tespit etmek adına İlişkili Ölçümler T-testi uygulanıp yorumlanmıştır.

Öğrencilerin bilimsel süreç beceri testindeki başarıları, her bir soruya verdikleri doğru cevaplar 1 yanlıș cevaplar 0 puan kabul edilerek hesaplanmıştır. 19 soru ile maksimum 19 puan alınabilen bu test neticesinde ön test için öğrencilerin başarı puanlarının ortalaması $\overline{\mathrm{X}}=35,12$ olduğu hesaplanmıştır. $\mathrm{Bu}$ sonuçlara göre ön test için öğrencilerin başarı yüzdesi \%37 olarak hesaplanmıştır. Son test açısından ise öğrencilerin başarı puanlarının ortalaması $\bar{X}=41,94$ olduğu hesaplanıp, başarı yüzdelerinin ise $\% 67$ olduğu tespit edilmiştir. Bu sonuçlara göre, ön testte öğrencilerin bilimsel süreç becerilerinin ortalamaları birbirlerine yakın olmakla birlikte, son testte bilimsel süreç beceri ortalamalarının özellikle deney grubu lehinde farklılaştığı görülmektedir. Bu farklılık ise tablo 5 'te yer aldığ 1 gibidir.
Tablo 5. Öğrencilerin Bilimsel Süreç Beceri Testindeki Puanlarının Şubelere Göre Ortalamaları ve Standart Sapma Değerleri

\begin{tabular}{|c|c|c|c|c|c|c|}
\hline & Şube & $\begin{array}{c}\text { Mevcut } \\
\text { (N) }\end{array}$ & $\begin{array}{l}\text { Ortalama } \\
\qquad(\overline{\mathbf{X}})\end{array}$ & SD & $\begin{array}{c}\text { \%95 } \\
\text { arali } \\
\text { Alt } \\
\text { Limit }\end{array}$ & $\begin{array}{l}\text { g̈ven } \\
\text { Snda } \\
\text { Üst } \\
\text { limit }\end{array}$ \\
\hline \multirow{5}{*}{ 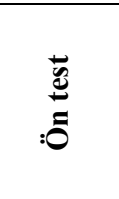 } & A & 20 & 35,50 & 5,826 & 32,77 & 38,23 \\
\hline & B & 24 & 39,58 & 8,587 & 35,96 & 43,21 \\
\hline & $\mathrm{C}$ & 25 & 34,00 & 7,906 & 30,74 & 37,26 \\
\hline & $\mathrm{D}$ & 36 & 32,78 & 12,215 & 28,64 & 36,91 \\
\hline & E & 24 & 35,00 & 10,108 & 30,73 & 39,27 \\
\hline Toplam & & 129 & 35,12 & 9,732 & 33,42 & 36,81 \\
\hline \multirow{5}{*}{ 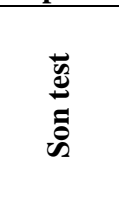 } & A & 57,00 & 8,335 & 8,335 & 53,10 & 60,90 \\
\hline & B & 58,13 & 10,406 & 10,406 & 53,73 & 62,52 \\
\hline & $\mathrm{C}$ & 37,00 & 12,829 & 12,829 & 31,70 & 42,30 \\
\hline & D & 32,64 & 12,677 & 12,677 & 28,35 & 36,93 \\
\hline & E & 32,29 & 9,205 & 9,205 & 28,40 & 36,18 \\
\hline Toplam & & 41,94 & 15,840 & 15,840 & 39,18 & 44,70 \\
\hline
\end{tabular}

Tablo 5'teki sonuçlara baktığımızda ön test sonuçları açısından öğrencilerin temel ve üst düzey bilimsel süreç becerilerinin başarı ortalamalarının birbirine yakın olduğu görülmektedir. Özellikle toplam standart sapma değerinin [SD=9,732] gibi düşük bir değerde olması ön test açısından grupların homojen olduğunu göstermektedir.

Tablo 5, son test sonuçları açısından ise ilginç sonuçlar vermektedir. Şöyle ki: deney grubu olarak belirlenen A ve B şubelerinin ortalamalarının $\left(\overline{\mathrm{X}}_{\mathrm{A}}=57,00 ; \overline{\mathrm{X}}_{\mathrm{B}}=58,13\right) \mathrm{C}, \mathrm{D}$ ve E şubelerindeki ortalamalardan $\left(\overline{\mathrm{X}}_{\mathrm{C}}=37 ; \overline{\mathrm{X}}_{\mathrm{D}}=32,64 ; \overline{\mathrm{X}}_{\mathrm{E}}=\right.$ $32,29)$ yüksek olduğunu göstermektedir. Son test açısından toplam standart sapmanın $[\mathrm{SD}=15,840]$ yüksek olması ise grupların heterojen olduğu sonucunu vermektedir.

Tablo 5, eleştirel pedagoji ilkelerine göre fen öğretimi yapılan A ve B şubelerindeki öğrencilerin temel ve üst becerinin daha yüksek olduğu sonucuna götürmektedir.

Tablo 6. Öğrencilerin Bilimsel Süreç Becerileri Testi Puanlarının Tek Faktörlü Varyans (ANOVA) Analiz Sonuçları

\begin{tabular}{|c|c|c|c|c|c|c|}
\hline & $\begin{array}{c}\text { Varyans } \\
\text { Kaynağı }\end{array}$ & $\begin{array}{c}\text { Kareler } \\
\text { Toplamı }\end{array}$ & df & $\begin{array}{c}\text { Kareler } \\
\text { Ortalamas1 }\end{array}$ & $\mathrm{F}$ & $\mathrm{P}$ \\
\hline \multirow{2}{*}{ } & $\begin{array}{l}\text { Gruplar } \\
\text { aras1 }\end{array}$ & 710,200 & 4 & 177,550 & 1,929 & , 110 \\
\hline & $\begin{array}{l}\text { Gruplar } \\
\text { içi }\end{array}$ & 11413,056 & 124 & 92,041 & & \\
\hline \multirow{4}{*}{ 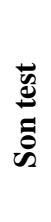 } & Toplam & 12123,256 & 128 & & & \\
\hline & $\begin{array}{l}\text { Gruplar } \\
\text { aras1 }\end{array}$ & 16781,615 & 4 & 4195,404 & 33,927 & ,000 \\
\hline & $\begin{array}{l}\text { Gruplar } \\
\text { içi }\end{array}$ & 15333,889 & 124 & 123,660 & & \\
\hline & Toplam & 32115,504 & 128 & & & \\
\hline
\end{tabular}

Tablo 6'da verilen varyans analizi sonuçları incelendiğinde şube farklılığının öğrencilerin bilimsel süreç becerileri testi puanına etki ettiği görülmüştür $\left[F_{4-124}=33,927 ; p<0,05\right]$.

$\mathrm{Bu}$ farklılaşmanın hangi gruplar arasında meydana geldiği araştırıldığında ise A grubundaki öğrenciler $(\overline{\mathrm{X}}=57,00)$ ile B grubundaki öğrencilerin $(\overline{\mathrm{X}}=58,13)$ lehine anlamlı bir farklılaşma tespit edilmiştir. Diğer taraftan $C, D$ ve $E$ grubundaki öğrenciler arasında bilimsel süreç becerileri testi puanları arasında anlamlı bir farklılık tespit edilememiştir. Bu sonuçları gösterebilmek için ise aşağıda verilen Tukey HSD çoklu karşılaştırma testi uygulanmıştır. 
Tablo 7. Bilimsel Süreç Beceri Testindeki Başarı Puanları Arasındaki Farkın Kaynağını Belirlemek Üzere Uygulanan Tukey HSD Testine İlişkin Sonuçlar

\begin{tabular}{|c|c|c|c|c|c|}
\hline & $\begin{array}{c}\text { Şube } \\
\text { (I) }\end{array}$ & $\begin{array}{c}\text { Şube } \\
(\mathbf{J})\end{array}$ & $\begin{array}{c}\text { Ortalamalar } \\
\text { farkı (I-J) }\end{array}$ & Sh & $\mathbf{p}$ \\
\hline \multirow{20}{*}{$\begin{array}{l}\vec{v} \\
: \tilde{\Xi} \\
: 0\end{array}$} & $\mathrm{~A}$ & $\mathrm{~B}$ & $-4,083$ & 2,905 & 625 \\
\hline & & $\mathrm{C}$ & 1,500 & 2,878 & ,985 \\
\hline & & $\mathrm{D}$ & 2,722 & 2,676 & ,847 \\
\hline & & $\mathrm{E}$ &, 500 & 2,905 & 1,000 \\
\hline & B & A & 4,083 & 2,905 &, 625 \\
\hline & & $\mathrm{C}$ & 5,583 & 2,742 & ,255 \\
\hline & & $\mathrm{D}$ & 6,806 & 2,528 & ,061 \\
\hline & & $\mathrm{E}$ & 4,583 & 2,769 & ,466 \\
\hline & $\mathrm{C}$ & A & $-1,500$ & 2,878 & ,985 \\
\hline & & B & $-5,583$ & 2,742 & ,255 \\
\hline & & $\mathrm{D}$ & 1,222 & 2,498 & ,988 \\
\hline & & $\mathrm{E}$ & $-1,000$ & 2,742 & ,996 \\
\hline & $\mathrm{D}$ & A & $-2,722$ & 2,676 &, 847 \\
\hline & & B & $-6,806$ & 2,528 &, 061 \\
\hline & & $\mathrm{C}$ & $-1,222$ & 2,498 & ,988 \\
\hline & & $\mathrm{E}$ & $-2,222$ & 2,528 & ,904 \\
\hline & $\mathrm{E}$ & A &,- 500 & 2,905 & 1,000 \\
\hline & & B & $-4,583$ & 2,769 & ,466 \\
\hline & & $\mathrm{C}$ & 1,000 & 2,742 & ,996 \\
\hline & & $\mathrm{D}$ & 2,222 & 2,528 & ,904 \\
\hline \multirow{20}{*}{ 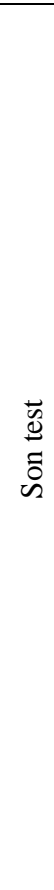 } & $\mathrm{A}$ & B & $-1,125$ & 3,367 & ,997 \\
\hline & & $\mathrm{C}$ & $20,000^{*}$ & 3,336 & ,000 \\
\hline & & $\mathrm{D}$ & $24,361^{*}$ & 3,101 & ,000 \\
\hline & & $\mathrm{E}$ & $24,708^{*}$ & 3,367 & ,000 \\
\hline & B & A & 1,125 & 3,367 & ,997 \\
\hline & & $\mathrm{C}$ & $21,125^{*}$ & 3,178 & ,000 \\
\hline & & $\mathrm{D}$ & $25,486^{*}$ & 2,930 &, 000 \\
\hline & & $\mathrm{E}$ & $25,833^{*}$ & 3,210 & ,000 \\
\hline & $\mathrm{C}$ & A & $-20,000^{*}$ & 3,336 & ,000 \\
\hline & & B & $-21,125^{*}$ & 3,178 & ,000 \\
\hline & & $\mathrm{D}$ & 4,361 & 2,895 &, 560 \\
\hline & & $\mathrm{E}$ & 4,708 & 3,178 &, 576 \\
\hline & $\mathrm{D}$ & A & $-24,361^{*}$ & 3,101 &, 000 \\
\hline & & B & $-25,486^{*}$ & 2,930 & ,000 \\
\hline & & $\mathrm{C}$ & $-4,361$ & 2,895 &, 560 \\
\hline & & $\mathrm{E}$ &, 347 & 2,930 & 1,000 \\
\hline & $\mathrm{E}$ & A & $-24,708^{*}$ & 3,367 & ,000 \\
\hline & & B & $-25,833^{*}$ & 3,210 & ,000 \\
\hline & & $\mathrm{C}$ & $-4,708$ & 3,178 &, 576 \\
\hline & & $\mathrm{D}$ &,- 347 & 2,930 & 1,000 \\
\hline
\end{tabular}

Tablo 7, bütün grupların (şubelerin) çoklu karşılaştırma test sonuçlarını içermektedir. Tukey HSD çoklu karşılaştırma testine göre; A ve B şubelerindeki öğrencilerin sahip olduğu grup ortalama puanları ile diğer grupların $(C, D, E)$ sahip olduğu grup ortalama puanları arasında $\% 95$ güvenle, deneyden önceki ve deneyden sonraki ortalamaları arasında anlamlı bir fark olduğunu göstermektedir $\left[\mathrm{F}_{4-124}=33,927\right.$; $\mathrm{p}<0,05]$.

Tukey HSD testine göre C,D ve E grubundaki puanların ortalamaları arasında ise anlamlı bir fark bulunamamıştır $\left[\mathrm{F}_{4}\right.$ $\left.{ }_{124}=1,929 ; \mathrm{p}>0,05\right]$.
Tablo 8. Öğrencilerin Bilimsel Süreç Becerileri Testinde En Çok Etkilenen Becerileri Belirlemek Üzere Uygulanan İlişkili Ölçümler T-Testi Sonuçları

\begin{tabular}{lccccc}
\hline \multicolumn{1}{c}{$\begin{array}{c}\text { Bilimsel Sürec } \\
\text { Becerileri }\end{array}$} & $\overline{\mathbf{X}}$ & $\mathbf{S d}$ & $\mathbf{t}$ & $\mathbf{d f}$ & $\mathbf{p}$ \\
\hline gözlem1 -gözlem2 &,- 455 & 5,151 &,- 585 & 43 &, 561 \\
\hline $\begin{array}{l}\text { sinıflama1 - } \\
\text { sinıflama2 }\end{array}$ & $-3,409$ & 4,283 & $-5,280$ & 43 &, 000 \\
\hline $\begin{array}{l}\text { Say1 uzay1-say1 } \\
\text { uzay2 }\end{array}$ & $-2,386$ & 3,492 & $-4,533$ & 43 &, 000 \\
\hline $\begin{array}{l}\text { verileri yorumlama1 } \\
\text { verileri yorumlama2 }\end{array}$ & $-2,273$ & 3,806 & $-3,961$ & 43 &, 000 \\
\hline $\begin{array}{l}\text { deney yapma1 } \\
\text { deney yapma2 }\end{array}$ & $-2,955$ & 3,785 & $-5,178$ & 43 &, 000 \\
\hline $\begin{array}{l}\text { hipotez kurma1 } \\
\text { hipotez kurma2 }\end{array}$ & $-4,205$ & 4,027 & $-6,926$ & 43 &, 000 \\
\hline $\begin{array}{l}\text { problemi belirleme1 } \\
\text { problemi belirleme2 }\end{array}$ & $-4,091$ & 3,620 & $-7,495$ & 43 &, 000 \\
\hline
\end{tabular}

Tablo 8'e göre öğrencilerin bilimsel süreç beceri testinde yer alan temel bilimsel süreç becerilerden olan gözlem becerisi için ön test ortalaması $(\bar{X}=8,86)$ ve son test ortalaması ise $(\overline{\mathrm{X}}=9,32)$ olarak elde edilmiştir. \%95 güven aralığında ise $\mathrm{p}$ değeri 0,05 üstünde $(p>0,05)$ çıkmıştır. Bu sonuca göre gözlem becerisi eleştirel pedagoji ilkelerine göre yapılan fen öğretiminden etkilenmemiştir. Yine temel süreç becerilerden olan sınıflama yapma becerisi için ön test ortalaması $(\overline{\mathrm{X}}=5,23)$ olurken son test ortalaması $(\overline{\mathrm{X}}=8,64)$ olmuştur. $\% 95$ güven aralığında bu beceri için $\mathrm{p}$ değeri 0,05 altında $(\mathrm{p}<0,05)$ çıkmıştır. $\mathrm{Bu}$ durumda sınıflama yapma becerisi eleştirel pedagoji sınıfinda yapılan fen öğretiminden etkilenmiştir. Sayı-uzay ilişkileri açısından (ön test $\bar{X}=5,11$, son test $\bar{X}=7,50$ ) olarak elde edilip $p$ değeri 0,05 altında ( $p<$ $0,05)$ gözlenmiştir. Sayı-uzay ilişkileri becerisi de eleştirel pedagoji sınıfındaki fen öğretiminden etkilenmiştir diyebiliriz. Buna benzer olarak üst düzey becerilerinden olan verileri yorumlama becerisi için (ön test $\bar{X}=5,00$, son test $\bar{X}=7,27 ; p<0,05$ ), deney yapma becerisi için (ön test $\bar{X}=5,00$, son test $\bar{X}=7,95, p=0,05$ ), hipotez kurma becerisi için (Ön test $\bar{X}=4,32$, son test $\bar{X}=8,52 ; p<0,05)$, problemi belirleme becerisi için (ön test $\bar{X}=4,32$, son test $\bar{X}=8,41 ; p<0,05$ ) olarak elde edilmiştir. $\mathrm{Bu}$ sonuçlara göre üst düzey becerilerden olan verileri yorumlama, deney yapma, hipotez kurma ve problemi belirleme becerileri eleştirel pedagoji ilkelerine göre yapılan fen öğretiminden etkilenmiştir diyebiliriz.

\section{Sonuç, Tartışma ve Öneriler}

$\mathrm{Bu}$ araştırmada, eleştirel pedagoji ilkeleri dikkate alınarak yapılan fen öğretiminin öğrencilerin bilimsel süreç becerilerine olan etkileri tespit edilip yorumlanmıştır. Fen bilimleri öğretim programı eleştirel pedagojinin temel yaklaşımlarından olan "özgür müfredat" yapma ilkesine göre uyarlanıp elde edilen sonuçlar açısından bir bakış açısı oluşturulmaya çalışılmıştır. Fen öğretimine tamamıyla eleştirel pedagoji ilkeleri açısından yaklaşıllıp bilimsel süreç becerilerinin gelişmesinde engel olduğu düşünülen geleneksel anlayışa reddiye getirilmeye çalışılmıştır. $\mathrm{Bu}$ doğrultuda fen öğretimi boyunca kendini gösteren bilimsel süreç becerilerini daha aktif hale getirebilmek adına fen öğretmenlerinin eleştirel pedagoji ilkelerinden olan özgür müfredat ve öğrenci bazlı öğretim programlarını daha çok dikkate almaları gerektiği şeklinde bir sonuçla karşılaşılmaktadır. Başka bir deyişle eleştirel pedagojik eğitim yaklaşımlarını daha çok içselleştirmeleri gerektiğine 
dair bir algı durumuyla baş başa kalınarak Giroux'ın (1979) eleştirel dili olabilirlik dili ile bütünleştirmeleri gerekir ifadesi bir kez daha kendini göstermektedir. Bu anlamdaözellikle çalışma boyunca öğrencilerin yaptığı fen bilimleri öğretim programının verdiği sonuçlara göre- öğretmenler, bilimsel süreç becerilerini geliştirmek adına fen öğretim programında yer alan ya da yer alacak olan etkinlik ve deneyleri günlük hayat ile daha çok bağlantılı pragmatist karşılığı olan ve sosyal hayat beklentilerini de dikkate alarak seçmeleri gerekmektedir. Bu doğrultuda öğrencilere gözlem ve deneyden vazgeçmeyerek elde ettikleri sonuçları sosyal hayat ile entegre edip özgür ve özgün bireyler olarak bilgiye ulaşmaları gerektiğini telkin ederek gerek sınıf içerisinde gerekse kamusal yaşamda değişim meydana getirebilecek analiz dillerini oluşturmaları gerekmektedir (Aksakallı, Salar \& Turgut, 2018). Bu doğrultuda fen grubu öğretmenlerinin bilimsel süreç becerilerini geliştirebilmek adına dönüştürücü parametreleri keşfedip bunların geliştirilebilmesi için ciddi atılımlar yapmaları gerekli görülmektedir.

Öğrencilerde bilimsel süreç becerilerini daha aktif hale getirebilmek her şeyden önce özgür ve demokratik öğretim programlarının oluşturulmasından geçmektedir. Özgür bir sınıf ortamında öğrenci bazlı öğretim programları kendini göstereceğinden öğrencilerin kendi beklentileri doğrultusunda hızla yükselen bilimsel süreç becerileri ile karşılaşmak da kaçınılmaz olacaktır. Öğrenci bazlı öğretim programları sınıfın asıl bireyleri olan öğrencileri nesne konumundan kurtarıp özne durumuna dönüştüreceğinden birçok alanda olduğu gibi bilimsel süreç becerilerinde de ciddi pozitif dönüşümler meydana getireceği düşünülmektedir. Bunların gerçekleşmesinde baş aktör olan öğretmenler ise sınıf içerisinde var olan eğitsel olayları, gerginlikleri ve olanakları değişime dönüştürecek bir dil geliştirmeleri gerekmektedir (McLaren, 2011). Özellikle geleneksel pedagojinin öğrencileri anlamaktan ne kadar uzak olduğunu düşündüğümüzde bilimsel kavramlardan ne kadar eksik kaldıklarını anlamak pek de görünmemektedir. Bu nedenle öğrencilerin bilim ve teknolojideki hızlı gelişmelerini kendi yararlarına kullanabilmeleri için fen eğitimini daha radikal boyutlara taşıyıp genel anlamda özgürleştirmek için fen eğitimcilerine yeni bir eleştirel söylem getirmeyi zorunlu kılmaktadır. Böyle bir söylem ise sınıfların yeni kimlik kazanması bağlamında fen eğitimcileri ve diğer eğitimciler açısından hayati önem taşımaktadır.

$\mathrm{Bu}$ çalışmada öğrencilerin bilimsel süreç becerilerinde meydana gelen değişimi görmek adına oluşturulan eleştirel pedagojik sınıflardaki öğrencilerin, eleştirel pedagoji ilkeleri ile büyük uyum sergiledikleri tespit edilmiştir. Özellikle Tukey HSD sonuçları sınıf bazlı öğretim programlarının öğrencilerin daha çok dikkatini çektiğini vurgulamıştır. Giroux'un (1979) ifade ettiği gibi eleştirel dil sadece uygulayıcıların kapasitelerini artırmakla kalmamakta, aynı zamanda eleştirel öğrenme ve sosyal güçlendirme gibi pedagojik bilgilerle de bağdaştırmaktadır.

Bilimsel süreç becerilerini pozitif yönde daha radikal boyutlara getirebilmek adına eleştirel pedagoji, fen öğretimine yeni bir bakış açısı getirmektedir. Bu bakış açısı, fen öğretiminde yeni bir kimlik kazandırması bakımından fen öğretmenlerine hayati bir görev yüklemektedir.

$\mathrm{Bu}$ çalışmada 24 hafta boyunca eleştirel pedagoji ilkeleri dikkate alınarak deneysel gruplarda yapılan fen öğretiminin öğrencilerin bilimsel süreç becerilerinde meydana getireceği değişimler tespit edilmeye çalışılmıştır. Çalışmadan elde edilen olumlu dönütler dikkate alındığında eleştirel pedagoji ilkelerine göre yapılan fen öğretimi dilinin öğrenciler tarafından beklenen bir sonuç olarak kendini gösterdiği görülmektedir. Bu bağlamda eleştirel pedagojik fen öğretimi dili, fen gurubu ögretmenleri tarafından dikkate alınması gereken bir zorunluluk olarak açığa çıkmaktadır. Özellikle öğretim programı yapma aşamasında kullanılan diyalogcu dil, öğrencilerin öğretmenlerden umduğu bir beklentiye dönüşmüştür. Öğretmen ve öğrencilerin birbirlerini anlayabilmesi bu dili daha çok kullanabilmekten geçtiği söylenebilir.

Eleştirel pedagoji ilkeleri dikkate alınarak yapılan fen öğretiminde öğrencilerin bilimsel süreç becerilerinde meydana gelebilecek değişimi tespit etmeyi amaçlayan bu çalışmada 24 hafta boyunca deney gruplarında eleştirel pedagoji ilkelerine göre fen öğretimi yapılırken kontrol gruplarında mevcut fen öğretimi program dili uygulanmıştır. Yapılan analiz sonuçlarında deney grubundaki öğrencilerin bilimsel süreç becerilerindeki değişimin olumlu yani pozitif yönde olduğu tespit edilmiştir. Bilimsel süreç becerilerindeki değişimi deney grubunun hazırladığı fen bilimleri öğretim programı üzerinden ölçmeyi hedefleyen bu çalışmanın sonuçları öğrencilerin bilimsel süreç becerilerinde meydana gelen değişimlerin deney grubu (A ve B) lehinde farklılaştığını göstermektedir. Yapılan betimsel istatistik analiz sonuçları deney grubu olan A ve B şubelerindeki öğrencilerin temel ve üst düzey becerilerinin, kontrol grubu olan $C, D$ ve $E$ şubelerindeki öğrencilerin temel ve üst düzey becerilerine göre daha yüksek olduğunu göstermiştir. Benzer şekilde Aksakallı, Salar ve Turgut (2018) tarafindan yapılan bir araştırmada da eleştirel pedagoji ilkelerine göre yapılan fen öğretiminin öğrencilerin akademik başarılarında olumlu değişimler meydana getirdiğini tespit etmişlerdir. Aynı şekilde Diaz'ın (2016) yaptığı bir araştırmada ise eleştirel pedagoji kullanılan sinıflarda öğrencilerin fen bilimleri dersindeki akademik başarılarının daha yüksek olduğunu açığa çıkarmıştır. Benzer şekilde Akbıyık'ın (2002) yaptığı bir çalışmada yüksek eleştirel eğilime sahip öğrencilere düşük düşünme eğilimine sahip öğrenciler arasında akademik başarı farkının olup olmadığı araştırılmıştır. Araştırmanın sonuçlarına göre yüksek eleştirel düşünme eğilimlerine sahip grubun genel akademik başarısı ile düşük eleştirel düşünme eğilimlerine sahip gruptan anlamlı düzeyde yüksek çıkmıştır. Paul ve arkadaşları ise (1992), 54 birinci sınıf mühendislik öğrencisiyle yaptıkları araştırmada öğrencilerin ders çalışma stratejileri ile eleştirel düşünme becerileri arasındaki ilişkiyi araştırmışlardır. Araştırma sonucunda eleştirel düşünme becerilerine sahip olan öğrencilerin eleştirel düşünme öğretiminde yeni materyalleri önceki bilgileriyle ilişkilendirmede daha başarılı oldukları görülmüştür.

Öğrencilerin bilimsel süreç beceri testinde en çok etkilenen becerileri belirlemek adına yapılan İlişkili Ölçümler T-testi sonuçları temel becerilerden olan gözlem becerisinin eleştirel pedagoji ilkelerine göre yapılan fen öğretiminden etkilenmediğini göstermiştir. Araştırma sonuçları temel bilimsel süreç becerilerinden olan gözlem becerisinin, beklentilerin tersi bir sonuç vermesi bakımından bu beceri ile ilgili daha fazla araștırma yapılması gerektiği sonucunu doğurmuştur. Temel bilimsel süreç becerilerinden olan sınıflama yapma ve sayı-uzay ilişkileri ise eleştirel pedagoji 
ilkelerine göre yapılan fen öğretiminden olumlu etkilendiği sonucuna ulaşılmıştır.

Araştırma; üst düzey beceriler olarak dikkate alınan verileri yorumlama, deney yapma, hipotez kurma ve problemi belirleme becerilerinin eleştirel pedagoji ilkelerine göre yapılan fen öğretiminden pozitif yönde etkilendiğini açığa çıkarmıştır. Benzer şekilde Walters ve Soyibo'nun (2001) yaptıkları bir çalışma, öğrencilerin üst bilimsel süreç becerileri düzeyleri ile okul tipi arasında istatiksel olarak güçlü bir ilişki olduğunu göstermiştir. Aynı şekilde Rezba ve arkadaşlarının (1995) yaptıkları bir çalışmada ise öğretmen adaylarının süreç becerileri başarısında ve ilköğretim sınıflarında bu becerilerin kullanımına yönelik üst düzey bilimsel süreç beceri öğretiminin etkinliğinde davranış gruplarının süreç becerilerinde istatiksel olarak daha yüksek başarı gösterdiklerini açığa çıkarmışlardır.

Sonuç olarak eleştirel pedagoji ilkelerine göre yapılan fen öğretiminde öğrencilerin temel ve üst düzey becerilerinin mevcut uygulanan fen bilimleri öğretim programına göre pozitif yönde değişimler meydana getirdiği tespit edilmiştir. Elde edilen bu sonuca göre eleştirel pedagojik dilin fen bilimleri öğretim programında dikkate alınması gereken bir dil olduğu söylenebilir. Bu doğrultuda fen eğitimine yer veren oluşumların, kendilerini bu dilden uzak tutmamaları önerilebilir. Bunun yanı sıra fen öğretmenlerinin bu dil ile tanışabilmeleri adına öğretmen yetiştiren kurumların öğretim programlarının içerisinde eleştirel pedagojik dile de yer vermeleri gerektiği söylenebilir. Araştırma sonucunda öğrencilerin kendi fen öğretim programlarını hazırlayarak kendi etkinlik ve deney listelerini hazırlamaları eleştirel pedagojik dilin özgürlükçü yapısının bilimsel süreç becerilerini artırdığını gözler önüne sermiștir. Bu anlamda öğrencilere sınıf içerisinde özgürlükçü kimliklerini ve buna bağlı ürün oluşturabilmeleri için gerekli firsatlar verilmelidir. Ayrıca bağımsız öğretim programı yapmanın demokratik bir hak olduğu bilinci oluşturulabilir. Bu bilinç 1şı̆̆ında 21. yüzyıl küreselleşen dünyasına ayak uydurabilmek için öğrencilerden söylenileni yapan değil; düşünen, sorgulayan, yargılayan, inceleyen, bilgi teknolojilerini kullanabilen, girișimci, yaratıcı ve eleștirel düşünebilen bireylere dönüşmesi sağlanabilir. $\mathrm{Bu}$ özelliklerin öğrencilere kazandırılmasında kuşkusuz okullar öncülük yapmalıdır. Bu amaçla okullarımızda okutulacak fen derslerinde yukarıda sayılan becerilerin kazandırılabilmesi adına eleştirel pedagojik dile de yer verilip fen öğretim programları yeniden tasarlanabilir. Araştırmanın sonuçlarına dayanarak fen bilimleri öğretmenlerine ve gelecek araştırmalara ilişkin öneriler aşağıdaki aşağıda maddeler halinde sunulmuştur:

1- Fen bilimleri öğretmenleri öğrencilere kendi fen bilimleri öğretim programını yapmaları konusunda bir şans verebilirler.

2- Bilimsel süreç becerilerinin geliştirilmesinde engel olduğu düşünülen geleneksel pedagojiden mümkün mertebe vazgeçebilirler.

3- Fen bilimleri öğretim programında yer alacak deney ve etkinlikleri günlük hayat ile bağlantılı olacak şekilde seçebilirler.

4- Sınıf içerisinde diyalogcu dili dada çok ön plana çıkarabilirler.
5- Temel bilimsel süreç becerilerden olan gözlem becerisi için eleştirel pedagojik ilkelerinden etkilenmemesi konusunda daha kapsamlı araştırmalar yapılabilir.

\section{Kaynakça}

Abruscato, J. (2000). Teaching children science: A discovery approach, 5th ed. Boston: Allyn and Bacon.

Akar, Ü. (2007). Öğretmen adaylarının bilimsel süreç becerileri ve eleştirel düşünme beceri düzeyleri arasındaki ilişki (Yayınlanmamış Yüksek Lisans Tezi). Afyon Kocatepe Üniversitesi Sosyal Bilimler Enstitüsü, Afyon.

Akbıyık, C. (2002). Eleştirel düşünme eğilimleri ve akademik başarı (Yayınlanmamış Yüksek Lisans Tezi). Hacettepe Üniversitesi Sosyal Bilimler Enstitüsü, Ankara.

Akdeniz, A. R. (2006). Problem çözme, bilimsel süreç ve proje yönteminin fen eğitiminde kullanımı. S. Çepni (Ed.). Kuramdan uygulamaya fen ve teknoloji ögretimi içinde (5.bask1, 107-133). Ankara: Pegem Yayıncılik.

Aksakallı, A., Salar, R. ve Turgut, Ü. (2018). Eleştirel pedagoji ilkelerine göre yapılan fen öğretiminin öğrencilerin akademik başarılarına etkisi. Anemon Muş Alparslan Üniversitesi Sosyal Bilimler Dergisi, 6(6), 961-971.

Althusser, L. (1991). Ideoloji ve devletin ideolojik aygitlart. İstanbul: İttihaki Yayınları.

Apple, M. (2004). Neoliberalizm ve eğitim politikalart üzerine eleştirel yazılar. (F. Gök, M. Apak, B. Can, D. Çankaya, F. Keser, H. Ala, Çeviri). Ankara: Eğitim Sen Yayınları.

Apple, M. W. (1982). Education and power. London: Routledge and Kegan Paul.

Apple, M. W. (2009). Müfredatın ve eğitimin yeniden yapılandırlmast/Neo-liberalizmin ve yeni muhafazakârlı̆̆ın gündemi. Eleştirel pedagoji söyleşileri. (E.Ç. Babaoğlu, Çeviri). İstanbul: Kalkedon Yayınları.

Applee, M., \& Beane, J. A. (2011). Demokratik okullar: Güçlü eğitimden dersler. (M. Sarı, Çeviri). Ankara: Dipnot Yayıncılık.

Arslan, A. (1995). Ilkokul öğrencilerinde gözlenen bilimsel beceriler (Yayımlanmamış Doktora Tezi). H.Ü. Sosyal Bilimler Enstitüsü, Ankara.

Arslan, A., G. ve Tertemiz, N. (2004). İlköğretimde bilimsel süreç becerilerinin geliştirilmesi. Türk Ĕgitim Bilimleri Dergisi, 2(4), 479-492.

Arthur, C. (1993). Teaching science through discovery. Toronto: Macmillan Publishing Company.

Ayaz, A., Akdeniz, A. R. ve Çepni, S. (1994). Fen bilimlerinde laboratuvarın yeri ve Önemi-I. Çăgdaş Ĕgitim, 19, 21-25.

Aydoğdu, B. (2014). Bilimsel süreç becerileri. Fen bilimleri ögretimi. Ankara. 
Baker, C. (2006). Zorunlu eğitime hayır. (A. Sönmezay, Çeviri). İstanbul: Ayrıntı Yayınları.

Berthoff, A. E. (1998). Okuryazarlık: sözcükleri ve dünyayı okuma. (S. Ayhan, Çeviri). Ankara: İmge Yayıncılık.

Blackwell, F. F., \& Hofmann, C. (1991). Science: Field test edition (High/Scope K-3 Curriculum Series).

Chomsky, N. (2007). Chomsky, demokrasi ve eğitim. (E. Abaoğlu, Çeviri). İstanbul: BGST Yayınları.

Christence, L. B., Johnson, R. B., \& Turner L. A. (2015). Research methods, design and analysis. (A. Aypay, Çeviri). Ankara: Anı Yayıncılık.

Çepni, S., Ayaş, A., Johnson, D. ve Turgut, M. F. (1996). Fizik ögretimi. Ankara: Milli Eğitimi Geliştirme Projesi Hizmet Öncesi Öğretmen Eğitimi Deneme Basımı.

Diaz, M. (2016). Critical pedagogy and student success: The transformative work of teaching and learning (Doctoral Dissertation). New Mexico State University.

Dökme, İ. (2005). Milli Eğitim Bakanlığı (MEB) İlköğretim 6. sınıf fen bilgisi ders kitabının bilimsel süreç becerileri yönünden değerlendirilmesi. IlköğretimOnline, 4(1), 7-17.

Dökme, İ. ve Ozansoy, Ü. (2004). Fen öğretiminde bilimsel iletişim kurabilme becerisi. XIII. Ulusal Eğitim Bilimleri Kongresi, 6-9.

Ergin, Ö., Şahin, E. Ş. ve Öngel, S. E. (2005). Kuramdan uygulamaya deney yoluyla fen ögretimi. İzmir: Dinazor Kitapevi.

Fischman, G. E., \& Mclaren, P. (2005). Rethinking critical pedagogy and the Gramscian and Freirean legacies: From organic to committed intellectuals or critical pedagogy, commitment, and praxis. Cultural Studies? Critical Methodologies, 5(4), 425-446.

Freire, P. (2006). Ezilenlerin pedagojisi. (D. Hattatoğlu, E. Özbek, Çeviri). İstanbul: Ayrıntı Yayınları.

Freire, P. (2009). Dönüşümün riskleri ve hissettirdiği korkular. Eleştirel pedagoji söyleşileri. (E. Ç. Babaoğlu, Çeviri). İstanbul: Kalkedon Yayınları.

Freire, P. (2010). Ezilenlerin pedagojisi. (D. Hattaoğlu ve E. Özbek, Çeviri). İsyanbul: Ayrıntı Yayınları.

Illich, I. (2009). Okulsuz toplum. (M. Özay, Çeviri). İstanbul: Şule Yayınları.

İnal, K. (2010). Eğitim ve iktidar. Ankara: Ütopya Yayınevi.

Karasar, N. (2004). Bilimsel araştırma yöntemleri. Ankara: Nobel Yayıncilık.

Kılıç, Z. Atasoy, S. Tertemiz, N. Şeren, M. ve Ercan, L. (2001). Konu alanı ders kitabı inceleme k1lavuzu fen bilgisi. Ankara: Nobel Yayıncılık.

Lind, K. (1998). Science process skills: Preparing for the future. Monroe 2-Orleans Board of Cooperative Education Services.
Freire, P., \& Macedo, D. (1998). Okuryazarlı: Sözcükleri ve dünyayı okuma. (S. Ayhan, Çeviri). Ankara: İmge Yayıncilık.

Geban, Ö. (1990). İki farkl ögretim yönteminin lise seviyesindeki öğrencilerin kimya başarllarına, bilimsel işlem becerilerine ve kimyaya karşı olan tutumlarına etkisi (Yayınlanmamış Doktora Tezi). Orta Doğu Teknik Üniversitesi Fen Bilimleri Eğitimi Bölümü, Ankara.

Germann, J. P., Aram, R., \& Burke, G. (1996). Identifying patterns and relationships among the responses of seventh grade students to the science process skills of designing experiments. Journal of Research in Science Teaching, 33(1), 79-99.

Giroux, H. A. (1979). Paulo Freire's approach to radical educational reform. Curriculum Inguiry, 9(3), 257272 .

Giroux, H. A. (2009). Dil/kültürel incelemeler alanında eleştirel pedagojinin bir rolü var mıdır? eleştirel pedagoji söyleşileri. (E. Ç. Babaoğlu, Çeviri). İstanbul: Kalkedon Yayınları.

Harlen, W. (1993). Teaching and learning primary science. London: ConvinPress.

Harlen, W. (1999). Purposes and procedures for assessing science process skills. Assessment in Education, 6(1), 129-144.

Hazır, A. (2006). İlköğretim 5. sınıf ögrencilerinin bilimsel süreç becerilerini edinebilme düzeyleri (Yayınlanmamış Yüksek Lisans Tezi) Afyonkarahisar Üniversitesi Sosyal Bilimler Entitüsü, Afyonkarahisar.

Hughes, C., \& Vade, W. (1993). Inspirations for investigations in science. Warwickshire: Scholastic Publicalion.

Huppert, J., Lomask S.M., \& Lazarorcitz, R. (2002). Computer simulations in the high school: students' cognitivestages,science process skills and academic achievement in microbiology. International Journal of Science Education, 24(8), 803-821.

Hurd, P. D. (1991). Why we must transform science. Educational Leadership, 49(2), 33-35.

Martin, D. J. (2003). Elementary science methods: A constructivist approach (3rd ed.). USA: Thomson Publishing Company.

McLaren, P. (1993). Schooling as a ritual performance: Toward a political economy of educational symbols and gestures. New York: Routledge

McLaren, P. (2011). Okullarda yaşam. Eleştirel pedagojiye giriş. Ankara: Anı Yayıncılık.

McLaren, P. L. (2003). Revulationary pedagogy in post revolution times. Rethinking the political economy of criritical education. New York and London: Routledge Falmer, 151-184. 
Ostlund, K. L. (1992). Science process skills: Assessingh ands-on student performance. New York: AddisonWesley.

Özoğlu, S. Ç. (1994). Bilim ve eğitim ilişkileri. Türkiye Bilimler Akademisi, Ankara, 75, 83.

Özsoy, S. (2004). Eşitlikçi bir eğitim deneyimi olarak köy enstitüleri. Eğitim Bilim Toplum Dergisi, 2(7), 4-25.

Padilla, M. J. (1990). The science process skills. Research Matters-to the science Teacher, 9004.

Paul, R., Binker., A. Jensen, K., \& Kreklau, H. (1990). Critical thinking handbook: K-4-6 guide for remodeling lesson plans in language arts, social studies and science. Sonoma State University, Rohnert Park, CA: Foundation for Critical Thinking.

Pekmez, E. Ş. (2001). Fen öğretmenlerinin bilimsel süreçler hakkındaki bilgilerinin saptanması. Maltepe Üniversitesi Eğitim Fakültesi Yeni Binyılın Başında Türkiye'de Fen Bilimleri Eğitimi Sempozyumu, İstanbul, 543-549.

Ramig, J. E., Bailer, J., \& Ramsey, M. J. (1995). Teaching science process skills. Torrance, California: Good Apple.

Rao, D. B., \& Kumari, U. N. (2008). Science process skills of school sdudents. Darya Gnaj, New Delhi: Discovery Publishing House.

Rezba, R. J., Sparague, C. S., Fiel, R. L., Funk, H. J. Okey, J. R., \& Jaus, H. H. (1995). Learning and assessing science process skills. Iowa: Kendall. cf

Rillero, P. (1998). Process skills and content knowledge. Science activities. Retrieved from http://www.sa.ebsco.com. September, 1, 2019.

Roberts, P. (2003). Knowledge, dialouge and humanization. critical theory and the human condition. Peter Lang, New York, 169-183.

Roberts, R., \& Gott, R. (1999). Procedural understanding: Its place in the biology curriculum. School Science review, 81(294), 19-25.

Saat, R. M. (2004). The acquisition of integrated science process skills in a web-based learning environment.
Research in Science ve Technological Education, 22(1), 23-40.

Sağıroğlu, N. A. (2013). Özgürleştirici eğitim arayışları: köy enstitüleri ve eleştirel pedagoji okulu. Amme İdaresi Dergisi,46(1), 81-98.

Sittirug, H. (1997). The predictivevalue of science process skills, attitude toward science, and cognitive development on achievement in a Thai Teacher Institution. (Unpublished Doctoral Dissertation), University of Missouri, Columbia.

Taşar, M. F., Temiz, B. K. ve Tan, M. (2002). İlköğretim fen öğretim programında hedeflenen öğrenci kazanımlarının bilimsel süreç becerilerine göre sinıflandirılması. V. Ulusal Fen Bilimleri ve Matematik Eğitimi Kongresi, 1, 380-385.

Temiz, B. K. (2001). Lise 1. sınıf fizik dersi programının öğrencilerin bilimsel süreç becerilerini geliştirmeye uygunluğunun incelenmesi (Yayınlanmamış yüksek lisans tezi). Gazi Üniversitesi Eğitim Bilimleri Enstitüsü, Ankara.

Temiz, B. K. ve Tan, M. (2003). İlköğretim fen öğretiminde temel bilimsel süreç becerileri. Eğitim ve Bilim, 28(127), 18-24.

Temizyürek, K. (2003). Fen öğretimi ve uygulamaları. Ankara: Nobel Yayıncılık.

Turgut, M. F., Baker, D., Cunningham, R., Piburn, M. ve Roger Cunningham (1997). İlkögretim fen ögretimi. Ankara: YÖK/DB Milli Eğitimi Geliştirme Projesi Hizmet Öncesi Öğretmen Eğitimi Yayınları.

Walters, Y. B., \& Soyibo, K. (2001). An analysis of high school students' performance on five integrated science process skills. Research in Science \& Technological Education, 19(2), 133-145.

Yıldırım, C. (1985). Bilim felsefesi. İstanbul: Remzi Kitapevi.

Yılmaz, K. ve Altınkurt, A. (2011). Öğretmen adaylarının eleştirel pedagoji ile ilgili görüşleri. Ahi Evran Üniversitesi Eğitim Fakültesi Dergisi, 12(3), 195213. 